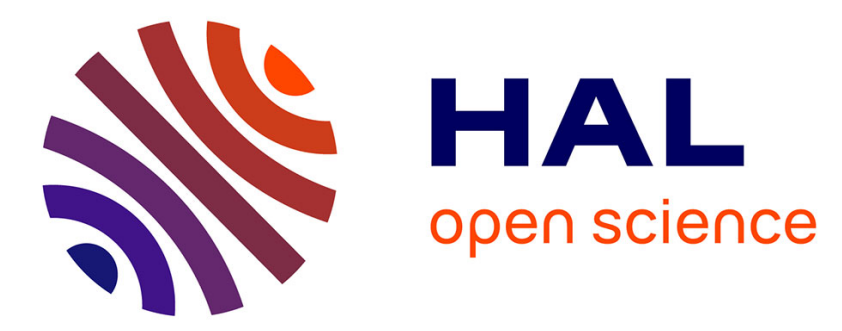

\title{
Impact of Shareholder-Value Pursuit on Labor Policies at Japanese Joint-Stock Companies: Case of Nikkei Index 400
}

\author{
Kostiantyn Ovsiannikov
}

\section{To cite this version:}

Kostiantyn Ovsiannikov. Impact of Shareholder-Value Pursuit on Labor Policies at Japanese JointStock Companies: Case of Nikkei Index 400. 2018. hal-01839679

\section{HAL Id: hal-01839679 \\ https://hal.science/hal-01839679}

Preprint submitted on 16 Jul 2018

HAL is a multi-disciplinary open access archive for the deposit and dissemination of scientific research documents, whether they are published or not. The documents may come from teaching and research institutions in France or abroad, or from public or private research centers.
L'archive ouverte pluridisciplinaire HAL, est destinée au dépôt et à la diffusion de documents scientifiques de niveau recherche, publiés ou non, émanant des établissements d'enseignement et de recherche français ou étrangers, des laboratoires publics ou privés.

\section{(ㅇ)(1) $\$$}

Distributed under a Creative Commons Attribution - NonCommercial - NoDerivatives| 4.0 


\title{
Impact of Shareholder-Value Pursuit on Labor Policies at Japanese Joint-Stock Companies
}

\section{Case of Nikkei Index $\mathbf{4 0 0}$}

\section{Kostiantyn Ovsiannikov}

\author{
University of Tsukuba
}

Doctoral Program in International and Advanced Japanese Studies

Prizewinner of the 2018 FFJ/SASE Best Paper Award

\section{July 2018}




\title{
Impact of Shareholder-Value Pursuit on Labor Policies at Japanese Joint-Stock Companies Case of Nikkei Index 400
}

\begin{abstract}
This paper aims at finding out how the shareholder-value pursuit has affected labor policies at large Japanese listed enterprises. It concentrates on the issue of labor bifurcation, whereby the proportion of nonregular employees has grown rapidly over the last two decades, currently approaching the numbers of regular employees.

In Japan, corporate governance reforms became key to structural macroeconomic changes according to the 2013 "Japan Revitalization Strategy" formulated by the Cabinet Office. This document mandated the creation of the JPX-Nikkei Index 400 - an index called to accommodate the most investor-friendly joint-stock companies. The move towards a shareholder model has been further reinforced through a rapid surge in foreign stockholding that started during the post-bubble period of the mid-1990s. At the same time, the externalities of increased returns to stockholders have been the changes in the related domains of management and labor, which I explain through the application of the political economic theory. This theory underlines the importance of inclusion into a "political bloc" for being eligible for economic benefits. Consequently, I argue that increased returns to politically privileged shareholders have been achieved at the expense of a growing proportion of unprivileged nonregular employees.

The evidence yields support to the argument about the positive correlation between shareholder value and the proportion of nonregulars. On the other hand, foreign stockholding does not appear to be significantly correlated with the increase in nonregular employment. In turn, the study has found that the proportion of nonregular employees is significantly correlated with domestic ownership that characterizes higher managerial entrenchment.
\end{abstract}

\section{Keywords}

Stakeholder Value; Shareholder Value; Corporate Governance; Labor; Nonregular Employment - JEL Codes: D02, G38, J21, P16.

\section{Acknowledgements}

This paper was presented for the first time during the 2018 SASE Annual Conference that was held in June 2018 at Doshisha University. A revised version of this paper is to be published in The Japanese Political Economy. The author may be contacted at k.ovsiannikov@gmail.com. 


\section{Contents}

$\begin{array}{ll}\text { 1. Introduction } & \text { p. } 4\end{array}$

$\begin{array}{ll}\text { 2. Literature Review } & \text { p. } 6\end{array}$

3. Research Operationalization: Shareholder Value and Nonregular Employment

p. 8

$\begin{array}{lr}\text { 4. Panel Data Analysis } & \text { p. } 12\end{array}$

4.1. Dependent variable: Ratio of Nonregulars p. 15

$\begin{array}{ll}\text { 4.2. Regression } & \text { p. } 16\end{array}$

$\begin{array}{ll}\text { 4.3. Results and Discussion } & \text { p. } 17\end{array}$

$\begin{array}{ll}\text { 5. Conclusions } & \text { p. } 23\end{array}$

$\begin{array}{ll}\text { 6. Limitations } & \text { p. } 23\end{array}$

$\begin{array}{ll}\text { Annexes } & \text { p. } 24\end{array}$

$\begin{array}{ll}\text { List of Figures and Tables } & \text { p. } 31\end{array}$

$\begin{array}{ll}\text { References } & \text { p. } 32\end{array}$ 


\section{Introduction}

With the current proportion of nonregular employees in Japan reaching 37.2 percent - a tremendous surge compared with 15 percent in early 1980s - this poses several social and economic challenges to the country (Labor Force Survey, 2017; Figure 1). Nonregular employment should ideally aim at aiding the economy in times of crisis. Otherwise, flexible employees should have prospects of attaining a regular status. This is not the case in Japan, as the chances of this growing labor cohort to become full members of their companies are significantly lower, compared to other developed countries (Aoyagi \& Ganelli, 2015). According to the Ministry of Health, Labour and Welfare (MHLW) survey (2016) and Labour Force Survey (2017), the average possibility for males to move from nonregular to regular employment in the first quarter of 2016 was six percent, and for females -2.7 percent. Flexibilization of labor is not a problem per se, if it exists in the environment with low labor turnover costs and representative unions, as in Nordic countries, also characterized by coordinated corporate governance (Witt \& Jackson, 2016). Contrary to that, Japan has not yet developed robust institutional mechanisms for protecting workforce not affiliated with a company on a long-term basis. Due to emerged gap between regular and nonregular employees, scholars observe rising poverty rate and wage insecurity leading to depressed domestic consumption, which deteriorates private sector accounts (Gordon, 2017). Another social consequence for nonregulars that follows is a falling confidence resulting in low degrees of marriage. This has wider repercussions by causing a plunge in birthrates (Gordon, 2017). Finally, as Japanese society ages, growing numbers of precarious workers lead to diminishing social insurance contributions making elderly people more vulnerable (Osawa, Kim \& Kingston, 2013).

Before 1984, when the share of nonregular employees in Japan was less than 15 percent, the voice of regular employees could be considered as roughly representative of the whole labor segment. However, as temporary workforce has been growing steadily since early 1980s, when their numbers were six million, they have reached over 20 million in 2017 (Labor Force Survey, 2017). Nonregular camp is nowadays composed of following categories: part-time workers (49\%), temporary workers / arubaito (21\%), contract employees (14\%), dispatched workers (6\%), entrusted employees (6\%) and others (4\%) (Labor Force Survey, 2017; Figure 2). Concurrently, numbers of regular workforce did not fluctuate significantly - the change has been from 33.3 million in 1984 to 33.85 million in 2017 (Labor Force Survey, 2017). Based on this evidence, Gordon (2017) concludes that the overall 35 percent increase in Japan's working population during the last 30 years is mainly due to the mentioned 14 million surge in nonregular workforce. This number can appear striking granted the fact that Japan's total population has increased during the

same period only by 6.46 million people (from 120.3 to 126.76 million) (Japan Statistical Yearbook, 2017). This seeming paradox can be explained by "a sharp contraction of 
self-employment and family labor, a rise in the numbers of the elderly and the proportion seeking work, and the increase of job-seeking women previously not in the wage labor force expanded the supply available for nonregular jobs" (Gordon, 2017, p. 16). Hence, the Japan's labor change over the last three decades can be summarized as the creation of numerous nonregular positions against the freeze in the hiring of regular employees.

This paper attributes the changes in human resource management (HRM) to the growing priority of the shareholder value pursuit by corporate managers. Although CEOs of large Japanese firms continue bearing monitoring functions, which protects them from immediate market-caused distortions, they also tend to become more focused on corporate profitability at the expense of growth. Managers have partially lost their immunity given by relational bank supervisors and have become increasingly subject to shareholders' pressure. In the resulting attempts to guarantee high share-value returns to investors, managers have tended to resort to corporate restructuring (Morgan \& Takahashi, 2002; Miyamoto, 2017).

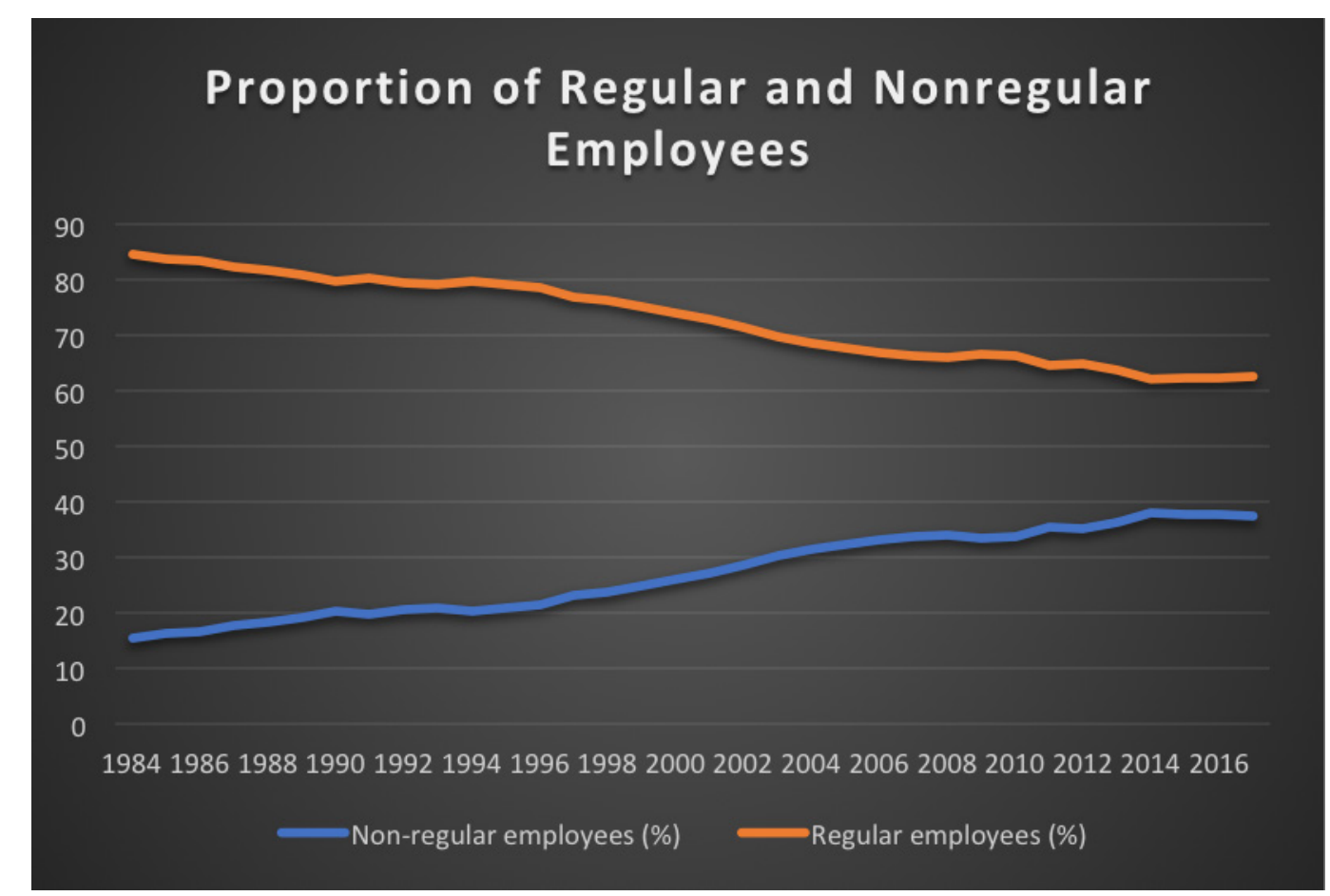

Figure 1. Proportion of Regular and Nonregular Employees. Source: Labour Force Survey (2017) 


\section{Types of Nonregular Employment}

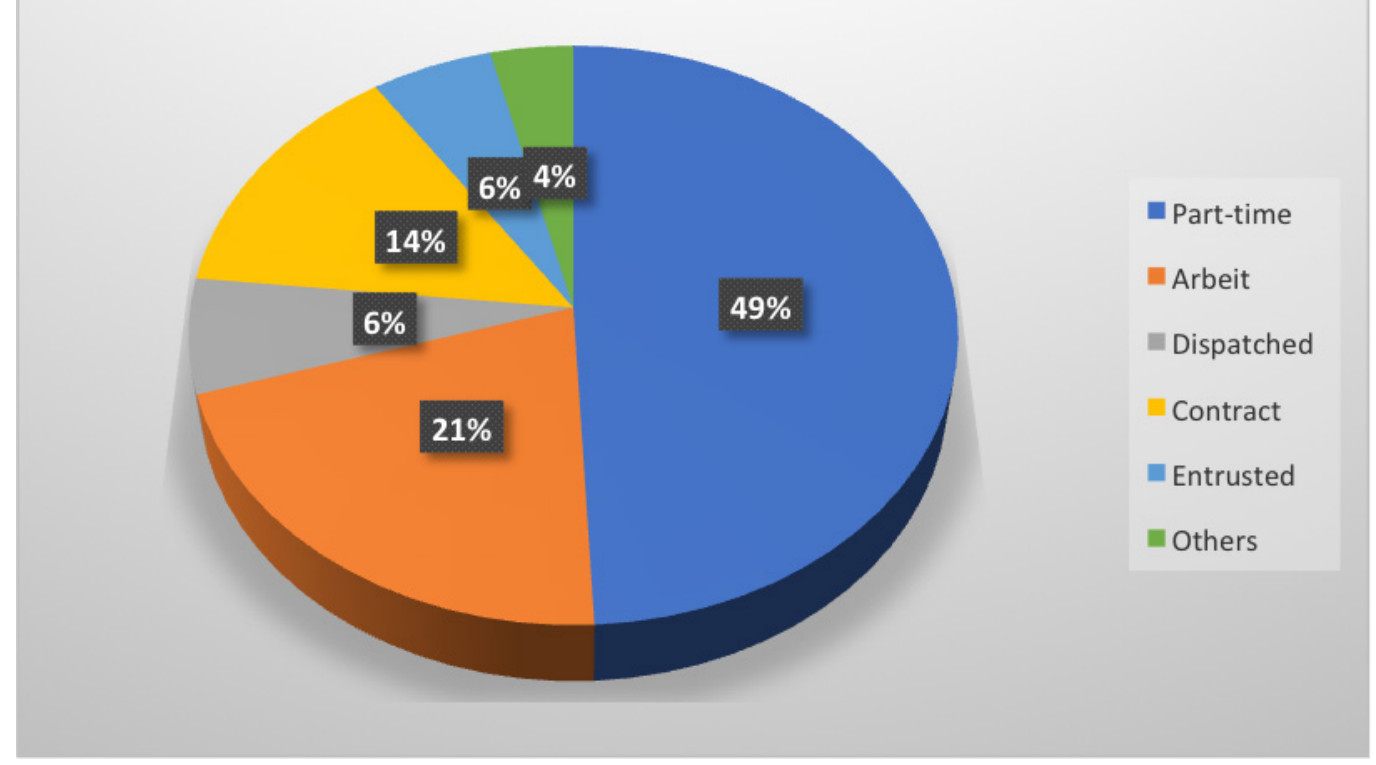

Figure 2. Types of Nonregular Employment. Source: Labour Force Survey (2017)

\section{Literature Review}

On the international level, Darcillon (2015) establishes a positive correlation between preferential shareholders' treatment (independent variable) and worsening conditions of blue-collar labor (dependent variable) across OECD states. Dore (2008) asserts the link between growing shareholders' power and decreased employees' tenure resulting from the intensified pressure from investors. Van der Zwan (2014) underlines ideological nature of financial reorientation towards shareholders that represents capitalist control mechanism. Aglietta (2000) describes a tendency towards labor bifurcation in the US, whereby lower remuneration for core as well as flexible employees is compensated in relation to the former group through stock-options' provision. Through application of institutional complementarity model, Amable et al. (2005) link low pressure from capital markets to cooperative management-labor bargaining and vice versa. This view is based on the notion that long-term "company-growth" strategy usually results in lower stock prices making a firm subject to potential hostile takeovers. Therefore, such strategy is more efficient and safe under low dependence on market, which is the case of bank finance as opposed to equity finance. Contrary to that, shareholder-oriented companies are subject to more immediate challenges that require focusing on profitability rather than long-term growth. Under these circumstances, management would be less willing to reinvest profits into corporate growth in general and to allocate it to employees (Höpner, 2005).

The literature on corporate financialization establishes a link between the relative growth of financial profits on one hand, and the widening income gap as well as the absence of wages' increments on the other (Palley, 2007). As the goals of companies become more finance-oriented, managers tend to concentrate on short-term market-based criteria, while 
neglecting firm-specific intangible assets (Gospel \& Pendelton, 2003). This is likely to result in the lack of attention to human resource development. Stockhammer (2010) mentions the increase in so-called "rentier income" that includes interest, dividend payments and bonuses, which is associated with the decline in labor costs.

As regards Japan, a systemic view on the roots of the growing proportion of nonregular employees can be captured by the "institutional complementarity" hypothesis. According to one of the general definitions provided by Crouch (2005, p. 359), it refers to a situation "where components of a whole mutually compensate for each other's deficiencies in constituting the whole". Masahiko Aoki (1994), who was the first to formulate the hypothesis, used it for explaining the institutional fit between contingent monitoring conducted by main banks and long-term employment relations in Japan. It is central to this paper due to its ability to capture the link between shareholder value pursuit and labor deregulation. In agreement with this thesis, the predominance of the in-house careers and the resulting high cost of job loss are institutionally complementary with long-term commitments toward employees (Tohyama, 2012). At the same time, those Japanese companies that have been most eager to implement shareholder-oriented policies since 1990s, have loosened employment guarantees (Jacoby, 2005). In order to both preserve institutional integrity and to pay tribute to shareholders' interests, employers have combined the retained guarantees for the core workforce with increased number of nonregular employees. By breaching the formerly encompassing management-labor compromise, directors have thereby discouraged employees from demanding the expansion of welfare spending (Tohyama, 2012).

The Japanese Institute for Labor (2010) also highlights the connection between growing shareholders' pressure and incremental change in the HRM, whereby seniority-merit and long-term employment are likely to decrease. Dore (2007) comes up with the argument about fundamentally conflicting interests of shareholders and employees resulting from the ongoing reform. Jackson (2007) formulates a similar thesis about an increasing role of market for corporate control in the shrinking proportion of core employees. Watanabe (2015, p. 59) applies an integral framework, arguing that financial / corporate deregulation on one hand, and labor deregulation on the other, are inseparable parts of a strategy aimed at "increasing functional flexibility and lowering production costs". Abe \& Hoshi (2007) show the complementarity between firm-centered employment and bank finance on one hand, and individual-centered employment and stock finance on the other. Conrad (2009) considers the possibility of shareholder-oriented reforms' resulting in a spread of pay-perperformance system, however does not come up with a definite conclusion. 


\section{Research Operationalization: Shareholder Value and Nonregular Employment}

Research Question: What has been the impact of shareholder value (SV) pursuit on labor policies of Nikkei Index 400 companies?

Literature gap. Available scholarship has not come up with robust explanations that would account for Japan's institutional features. In other words, existent literature does not provide a satisfactory answer to the question of why Japanese employers have decreased labor costs not through massive layoffs and overall flexibilization of labor conditions (which is the case of neoliberal policies in the West), but through increasing the proportion of nonregular employees amid retention of preferences for core workers. The basic answer is a tactic of killing two birds with one stone: preserving institutional integrity while at the same time paying tribute to shareholders' interests. Among the few studies that address this problem from institutional and political angles are Peng (2012), Song (2012), Thelen \& Kume (1999; 2006) and Yun (2015). I take the following argument of Song (2012, pp. 416417 ) as a starting point: "in Japan, political coalitions between conservative policymakers, large firms, and core regular workers were the driving force of the reinforcement of dualism and inequality by shielding labor market insiders from the pressure for regulatory reforms but extensively eroding regulations protecting outsiders for flexibility".

Suggested contribution. The offered theory is a political economic analysis of institutions. It is particularly well-suited for explaining institutional change like the one where elements of shareholder model are adopted in a stakeholder environment (Jackson, 2016). Political economic approach defines institutions as "political compromises among different interest groups that form socio-political coalitions to advance their interests" (Lechevalier et al., 2016, p. 6). It has been very recently that Yamada \& Hirano (2015) as well as Lechevalier et al. (2016) and Jackson (2016) have demonstrated the merits of applying political economic theory to the issue of intensified SV pursuit in Japan and its connection to labor deregulation. While their analysis is yet preliminary, current research incorporates and tests the view about the pursuit of SV being a political project aimed at power accumulation (Amable, 2016).

There are basically two different approaches to SV. One (1), advocated by agency theory representatives (Friedman, 1970; Jensen \& Meckling, 1976; Rappaport, 1986, Stewart, 1991), argues that a joint-stock company is solely a property of its stockholders. The function of managers-agents is to maximize SV under contractual obligations toward stockholders-principles. However, large Anglo-Saxon corporations are characterized by dispersed shareholding, which precludes investors from influencing the voting process at annual general meetings (AGMs). Instead, they can exercise their rights via the ability to sell their stock to an outside bidder. On the other hand, as managers become more autonomous, they claim higher rewards and credentials. If this is achieved at the expense of shareholders' returns, their actions are believed to cause "agency costs". To lower them, stock-listed companies must comply with internationally accepted accounting standards. 
Japanese stock-listed companies have been advised to use International Financial Reporting Standards (IFRS) by the Tokyo Stock Exchange in 2010. As of June 2017, 150 companies have decided or planned to adopt IFRS (JPX, 2017). Thereby, even under the absence of direct shareholders' supervision, CEOs are pushed to achieve higher returns to shareholders to sustain a competitive race. Thus, agency theory emphasizes a dogmatic task of CEOs to maximize SV, which is believed to be a primary task of a joint-stock company.

Since outside directors do not play a substantial role in Japan's corporate governance (only 2.5 percent of TSE 1 st and 2 nd section companies have adopted a U.S.-style "company-with-three-committees" that requires the majority of outside directors), Japan is a good case study to test the effects of SV implementation through accounting metrics. Japan Revitalization Strategy (2013) stresses the foundational role of Return on Equity $(\mathrm{ROE})$ as a crucial index to be pursued by managers for improving corporate productivity. Inagami \& Whittaker (2005) found out that Japanese CEOs are giving increasing priority to ROE due its ability to capture the efficiency of capital use against shareholders' investment. Therefore, according to Ito (2014, p. 56), "ROE improvement can be regarded as the core of the third arrow of Abenomics". Although there is a clear awareness of the ongoing prioritization of ROE for Japanese stock-listed companies (Milhaupt, 2017), agency theory does not question the implications of increased shareholder returns for labor policies.

Sato (2000, cited in Inagami \& Whittaker, 2005) measured the influence of ROA and EVA (economic value added) on lifetime employment policy but did not touch upon the issue of nonregular employment. One possible reason for the neglect of this aspect is that drastic increase in temporary employment occurred mainly during the recent decade and was quite a novel issue back in 2000. Another explanation is the problem of collecting data on nonregular employment, which is a significant impediment for the labor-related research (Lechavalier et al., 2014). Listed companies have started to publish the respective data only from 2008. Furthermore, it has been included into financial databases only from 2010. While the levels of SV are not the indicators of sustainable corporate growth, they nevertheless matter for market evaluation and, therefore, reputation of a firm. The following hypothesis aims to link SV with nonregular employment.

$\mathrm{H} 1$. Higher levels of SV are associated with higher proportions of nonregular employment.

The second (2) view on SV is more comprehensive. According to it, SV has become a contested concept due to widespread attempts to adhere to its standards by coordinated market economies (CMEs) of continental Europe and East Asia (Jürgens et al., 2000). The pursuit of SV as a primary goal of a public company in the Anglo-Saxon context is very different from the stakeholder model of corporate governance (CG) of CMEs that considers interests of "shareholders, employees, creditors, customers, and the society in which the corporation resides" (Fiss \& Zajac, 2004, p. 501). Thus, managerial merits under stakeholder model are not confined to SV returns. Moreover, managers experience less pressure from capital markets: their motivation rather stems from long-term commitments to company. On contrary, CEOs in the shareholder model are mainly disciplined by the threat of hostile takeovers if they fail to meet investors' demands (Deakin, 2005; Mitchell et 
al., 2005). As a result, while following the task to raise SV, managers commonly resort to restructuring through labor cuts (Darcillon, 2015). Against these societal externalities, there is a logical question about reasons for introducing shareholder features to stakeholder model. A possible prerequisite is a crisis of a national CG, which requires an adoption of a popularly-acclaimed alternative (Yoshikawa et al., 2007). In the case of Japan, sufficient analysis of compatibility with local institutions is often missing.

The salient stakeholder features of the local CG give yet another reason to critically examine the adoption of SV in Japan. Several studies confirm negative correlation of the SV pursuit and labor costs in Japan. Dore (2008) asserts the link between growing shareholders' power and decreased employees' tenure resulting from the intensified pressure from investors. Those Japanese companies that have been most eager to implement shareholder-oriented policies since 1990s, have loosened employment guarantees due to ascendance of SV along the hierarchy of corporate priorities (Jacoby, 2005). Whereas in the postwar period "the relationship between workers and managers was primary, and that between shareholders and managers was secondary", this order has been reversed from the late 1980s (Yamada \& Hirano, 2015, p. 14). Against economic slowdown in 1990s that followed the bubble burst, employers and business have eventually pushed for abandoning the annual negotiations with labor through shunto rounds (Uemura, 2012), which caused steady decrease in welfare spending (Tohyama, 2012).

To incorporate the political dimension into the analysis of SV repercussions for labor, I inquire, in whose interest the enhancement of shareholders' rights is. As already mentioned, CG reforms are a part of the governmental agenda, formulated in Japan's Revitalization Strategy (JRS) (2013). Therefore, CG changes promoted by the Cabinet Office are likely to influence the achievement of higher SV returns. According to the government's view, the targeted companies are primarily the ones included into the Nikkei Index 400 created in 2014 and described in JRS as one of the "initiatives aimed at enhancing the competitiveness of companies" (JRS, 2013, p. 76). The index is based on such quantitative achievements as: three-years average ROE and operating profit, as well as market value (JPX-Nikkei Index 400 Guidebook, 2016). Major qualitative requirements are: an appointment of at least two independent outside directors, and an adoption of IFRS (International Financial Reporting Standards) (JPX-Nikkei Index 400 Guidebook, 2016).

Another influential actor that has advocated shareholders' rights is foreign investors, which shareholding proportion was 30.1 percent as of 2016 (TSE, 2017, p. 2; Figure 3). Japanese companies with higher levels of foreign stockholding are characterized by higher risk-taking propensity (Yoshikawa et al., 2005; Nakano et al. 2014) and downsizing in the attempts to maximize SV (Ahmadjian \& Robinson, 2001; Ahmadjian \& Robbins, 2005). Conversely, domestic ownership proportion (Abe \& Shimizutani, 2007; Yoshikawa et al., 2005) and ownership concentration (Fiss \& Zajac, 2004; Witt \& Jackson, 2016) are associated with strategic rather than financial interests. 
H2. Foreign shareholding is positively related with proportions of nonregular employees.

The previous literature accounts for organizational size, age, reputation, wages, foreign ownership (Ahmadjian \& Robinson, 2001) and board size (Abe \& Shimizutani, 2007) as key determinants of corporate legitimacy in the Japanese context. This research comes up with another proxy, which is the inclusion into Nikkei Index 400. It is referred to as "shame index" for its utmost reputational importance for large companies (Patrick, 2015, p. 16).

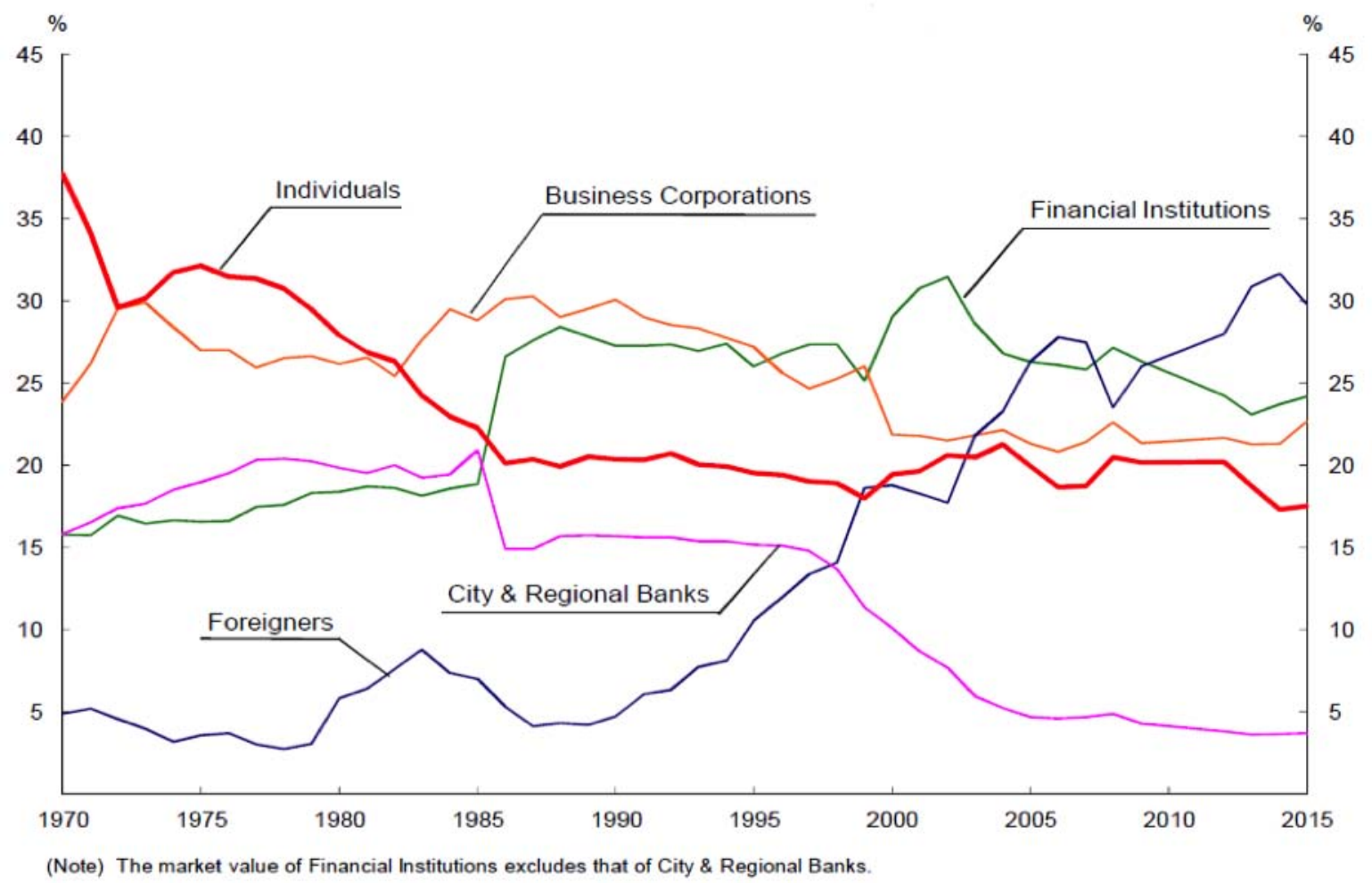

Figure 3. Distribution Percent of Market Value Owned by Type of Shareholder. Source: Tokyo Stock Shareownership Survey (2017)

The presented evidence about the importance of reputational assets for Japanese listed companies being relevant, requires an important clarification. A key economic reason for implementing the CG reforms agenda has been the shrinking domestic market that has induced companies to search for export-oriented strategies (Milhaupt, 2017). In other words, internationalization has been regarded as a means for sustainable corporate growth. In order to attract more investment and be able to expand globally, companies need to adhere to recognized accounting and CG standards. However, not all the firms have succeeded to internationalize. With the weakening of business-finance nexus in early 1980s, large multinational companies (MNCs) became less dependent on a national industrial policy, which allowed them "to allocate resources based on corporate strategy mainly oriented to maximize [their] position in global value chains" (Lechevalier et al., 2016, p. 25). This has helped them to alleviate the consequences of the 1990s' bubble burst (Yamada \& Hirano, 2015). On the contrary, internally-focused companies have been much more dependent on partner banks and less capable of issuing equity, which would potentially improve their accounts. Hence, while MNCs have been increasing their internal reserves by issuing stock and investing overseas, domestic-oriented companies have been mostly concerned 
with repaying debts, which made their growth almost negligible - much in line with minimal growth of Japan's GDP during the last three decades.

In their similar study, Yoshikawa et al. (2005) used return on assets (ROA) as a moderating variable reflecting firms' performance. Other moderating variables include R\&D intensity and the "degree of internationalization" $(D O /)$. Existent scholarship links higher degrees of R\&D intensity to lower financial pressure (Gospel \& Pendelton, 2003). In other words, managers whom creditors offer longer pay-back periods, enjoy more freedom of investing into long-term projects, including various forms of human resource development. Thus, R\&D intensity is negatively correlated with employment downsizing (Lechevalier et al., 2014). The proxy for DOI is FSTS (Foreign Sales as a Percentage of Total Sales), which is the most common method used in previous studies (Sullivan, 1994). DOI is regarded in the literature as a stimulation for labor downsizing due to pressures related to international competition (Lechevalier et al., 2014). However, while more internationalized companies might resort to more frequent downsizing, it is not evident, whether they are likely to increasingly rely on nonregular workforce. Based on this consideration, I offer the following hypothesis:

H3. $D O I$ and $R \& D$ are negatively correlated with ratio of nonregular employment.

\section{Panel Data Analysis}

Sources: NEEDS FinancialQUEST database and annual securities reports of Nikkei Index 400 companies retrieved from kabupro.jp.

Selection criteria: Nikkei Index 400 is a political economic project outlined in Japan Revitalization Strategy as one of the "initiatives aimed at enhancing the competitiveness of companies" (Japan Revitalization Strategy, 2013, p. 76). The index consists mostly of large companies that are subject to internationalization and thereby decoupling from national economy. It supposedly: (1) encompasses interest of non-stable shareholders, management and core employees to the highest degree while (2) downplaying interests of nonregular employees.

Dependent variable: Proportion of nonregular employees

\section{Independent variables:}

- Shareholder value (SV) proxies:

- Tobin's Q ( $Q=$ Equity Market Value $\div$ Equity Book Value) (Nakano et al., 2014)

- $\quad$ Total shareholder return $(T S R=$ Share price at end of year - Share price at the beginning of the year + Dividends per share) $\div$ Share price at beginning of year) (Dobbs \& Koller, 2005)

- Director ownership: shows the degree of alignment between directors and 
shareholder and, hence, the extent of directors' potential compliance with shareholders' clams to raise SV (Gospel \& Pendelton, 2003)

- Annual general meeting (AGM). Japan's AGMs are often held on a same day and within a short period of time. This measure was introduced to formalize meetings and limit outside shareholders' interference. Thus, I differentiate between companies that chose to hold AGM during the most popular day ("1"), indicating limited shareholders' influence, and the rest ("O"), more opened to shareholders' demands

- Foreign ownership

- Profitability proxy: return on assets $(\mathrm{ROA}=\mathrm{NI} \div \mathrm{TA}$, where $\mathrm{NI}$ is net income, $\mathrm{TA}$ is total assets) (Ahmadjian \& Robbins, 2005)

- Domestic ownership proxy: other companies' ownership + financial ownership

- Size proxy: total assets

- Productivity proxy: net sales $\div$ number of employees (Ahmadjian \& Robinson, 2001)

\section{Control variables:}

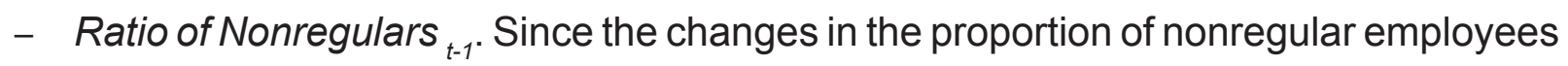
are incremental, I include the dependent variable lagged by one year as a control variable

- Degree of internationalization $(D O /)$ : exports $\div$ net sales

- R\&D intensity: R\&D expenses $\div$ net sales

The analyzed panel data sample contains 245 firms belonging to the Nikkei Index 400 with data from 2010 till 2017. Each company's data encompasses the period between two and eight years, which makes the panel unbalanced. I excluded financial companies due to their different accounting standards. Because of the limited availability of information on nonregular employees in the NEEDS FinancialQUEST database, the starting year of analysis is 2010 , the final year is 2017 , which makes 1762 observations in total. I used R software (R Core Team, 2017) that includes various statistical packages to analyze and visualize data. The used packages are: "ggplot2" (Wickham, 2009), "Ime4" (Bates et al., 2015), "plm" (Croissant \& Millo, 2008), "sjmisc" (Lüdecke, 2018), "sjPlot” (Lüdecke, 2018b) and "stargazer" (Hlavac, 2018). 


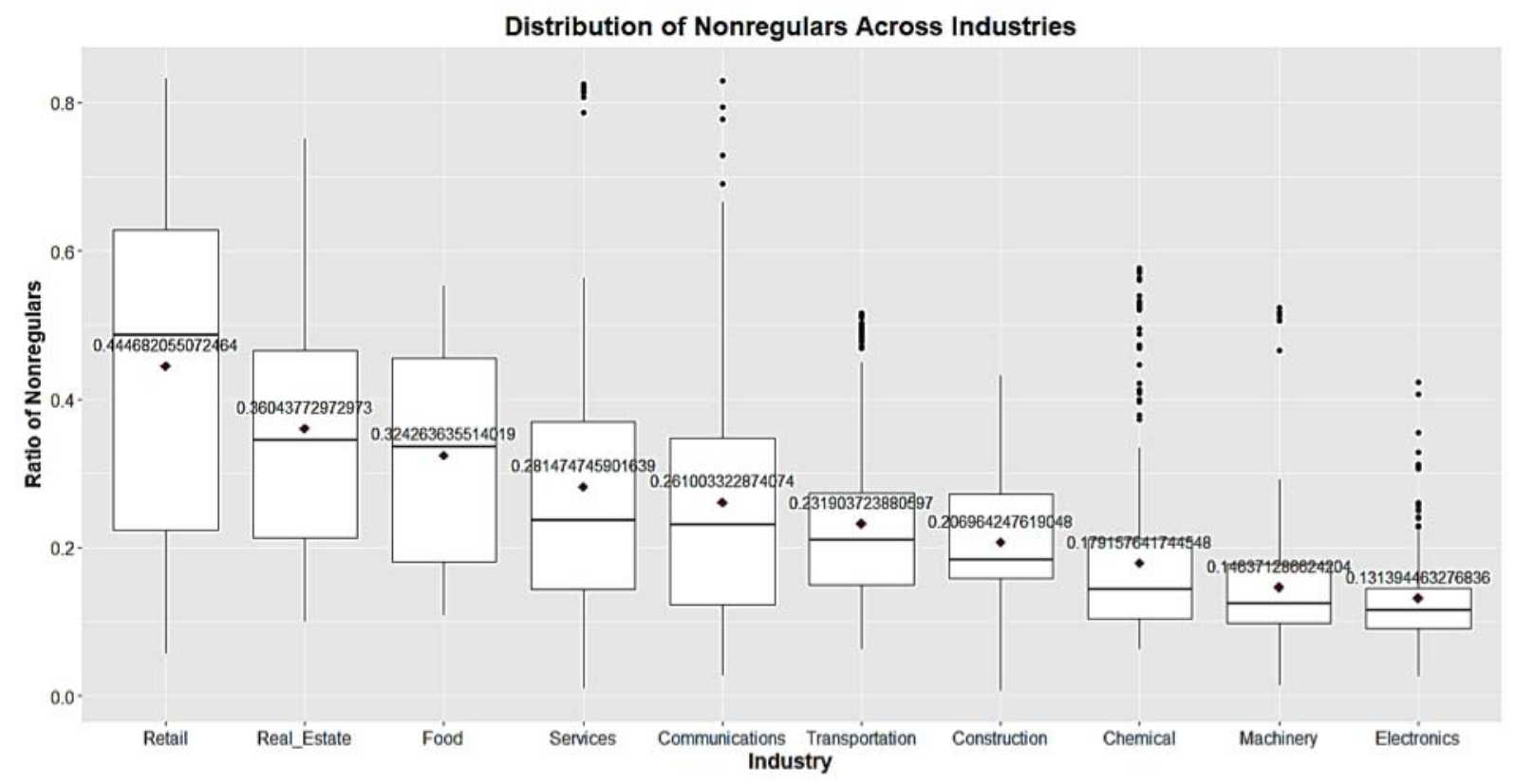

Figure 4. Distribution of Nonregulars Across Industries

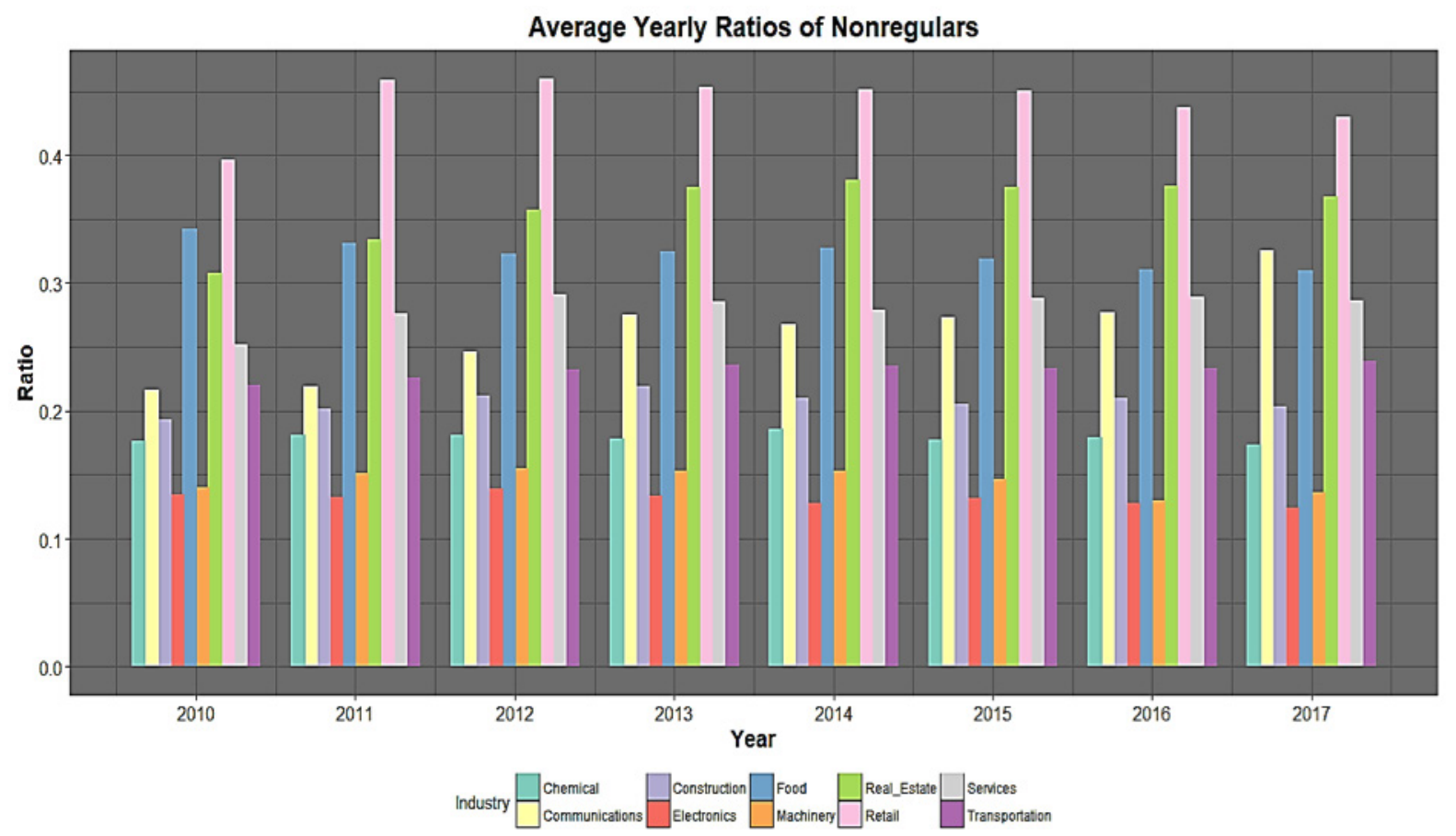

Figure 5. Average Yearly Ratios of Nonregulars 


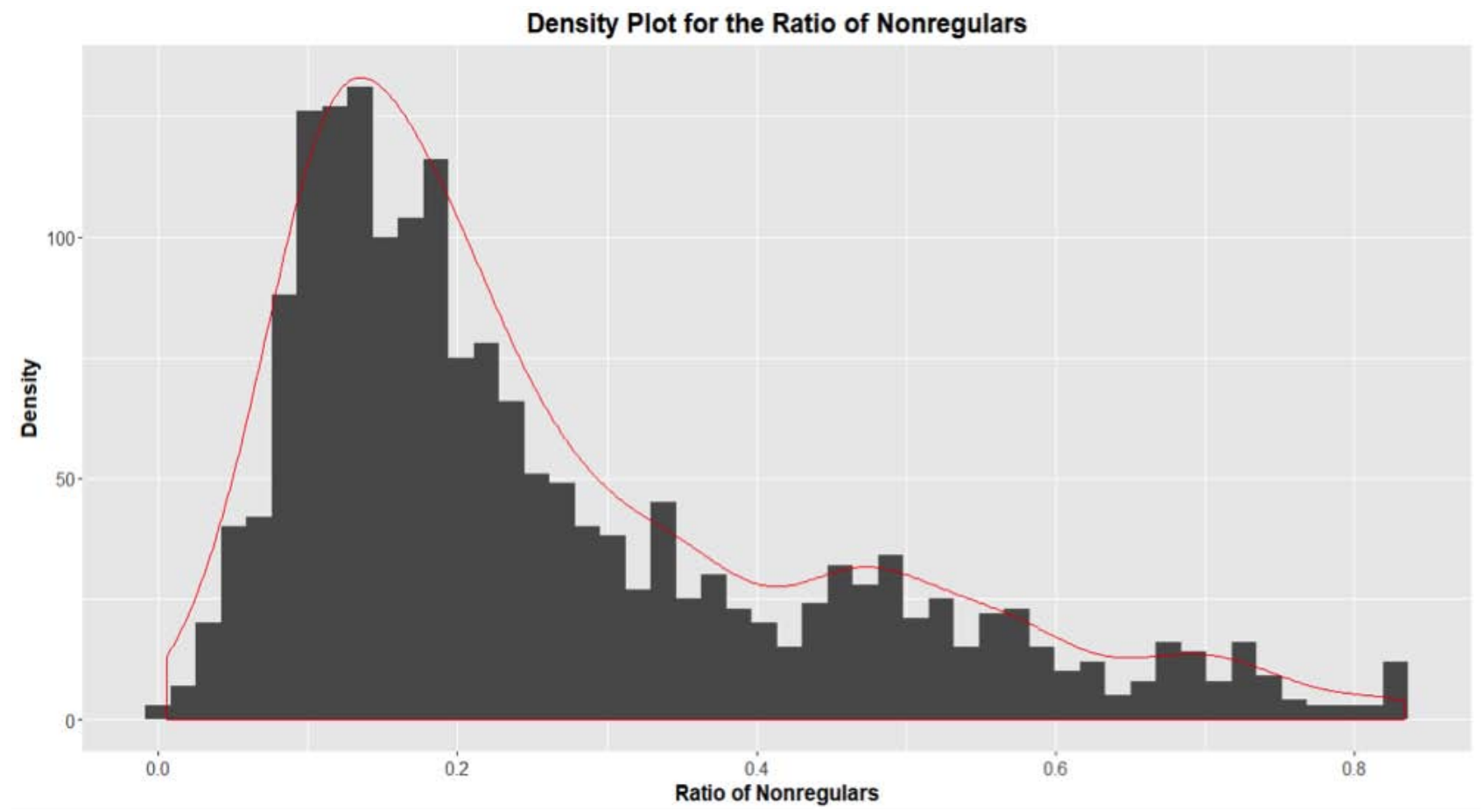

Figure 6. Density Plot for the Ratio of Nonregulars

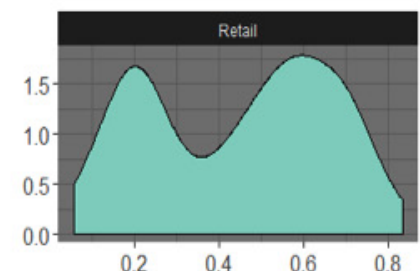

\section{Density Plot for the Ratio of Nonregulars by Industry}
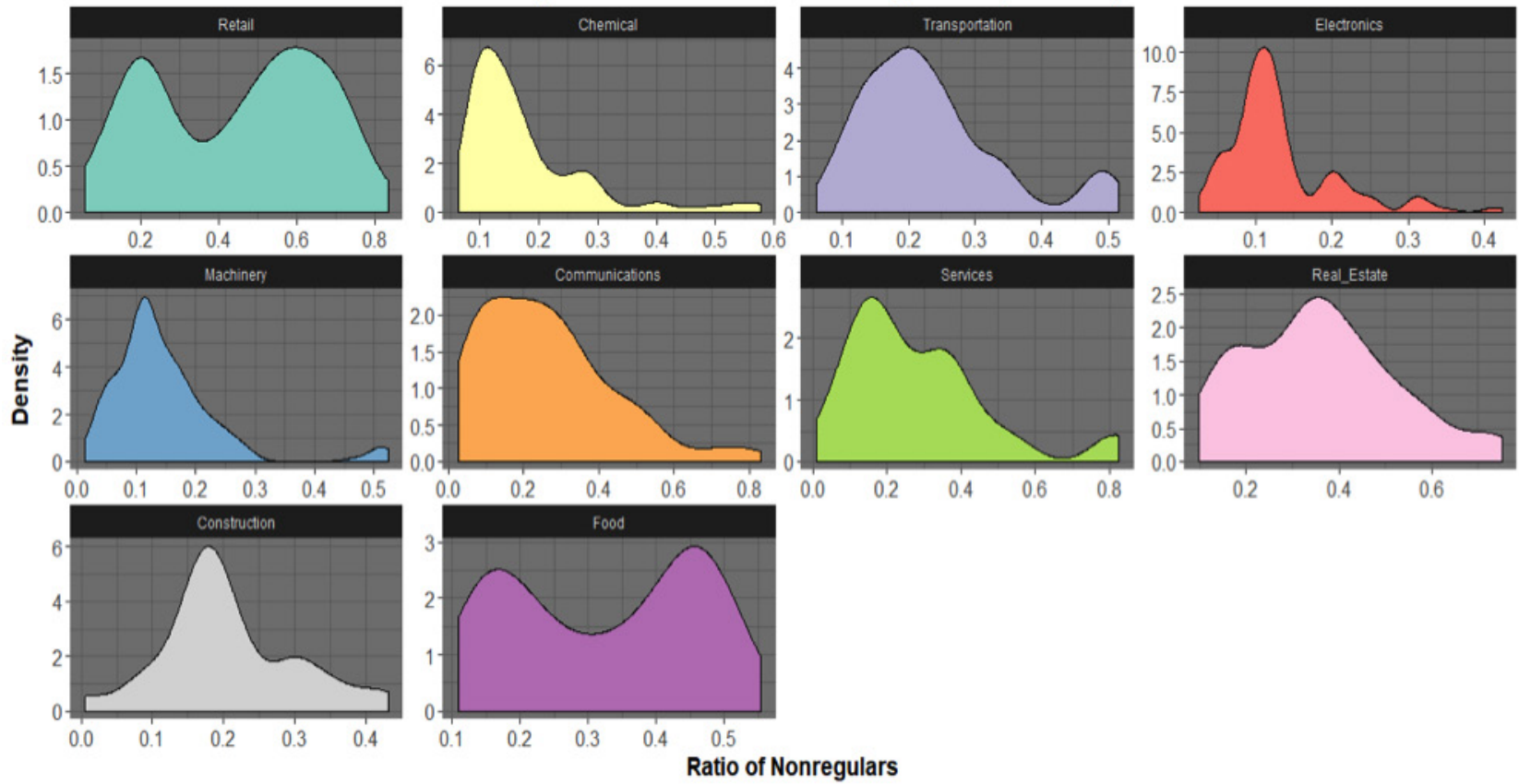

Figure 7. Density Plot for the Ratio of Nonregulars by Industry

\subsection{Dependent variable: Ratio of Nonregulars}

As seen from the Figure 4, companies belonging to the "Retail", "Real Estate" and "Food" industries have the highest median and average ratios of nonregulars, while "Electronics", "Machinery" and "Chemical" employ the lowest proportions of temporary employees. The same observation holds true for the yearly averages per industry, which 
can be inferred from the Figure 5. Such distribution is logical, since companies with highest proportions of nonregular employees belong to labor-intensive industries, which means they can improve their balance sheets by decreasing average labor costs. On the other hand, companies belonging to capital-intensive industries have the lowest rates of temporary employees. Their profits are less dependent on human resources, and, hence, there is not much rationale to curb labor cost per employee.

The distribution of the dependent variable "Ratio of Nonregulars" is skewed to the right, as seen from the Figure 6 . From this type of distribution, we can corroborate that the mean is larger than the median. The descriptive statistics table (Table 1) proves this. We can also infer from the density plot (Figure 6) that the distribution is bimodal (the third mode can be distinguished towards the right end of the distribution, but it is less evident). It can be corroborated from the Figure 7 that the distribution of nonregulars that closely resembles the general right-skewed bimodal pattern is observed for such industries as: Chemical, Electronics (which also has a third mode), Machinery and Services.

\subsection{Regression}

The $\mathrm{F}$ test showed a low $\mathrm{p}$-value $(<2.2 \mathrm{e}-16)$, which counts against the null hypothesis that the "pooled OLS model" is adequate, in favor of the fixed effects alternative. The Breusch-Pagan test for unbalanced panels showed a low p-value $(<2.2 \mathrm{e}-16)$, which also counts against the null hypothesis that the "pooled OLS model" is adequate, in favor of the "random effects model" alternative. Finally, the Hausman test showed a low $p$-value $(<2.2 \mathrm{e}-$ 16 ), which counts against the null hypothesis that the "random effects" model is consistent, in favor of the "fixed effects model". Although the "fixed effects model" appears the most appropriate for my data, to demonstrate the similarities/differences in these models and to improve the robustness of the analysis, I include all three of them into the comparative regression tables.

As for the "fixed effects model", I have run two regressions with the "individual" and "two-ways" effects respectively (both have the p-values $<0.01$, meaning high levels of significance). While the "individual" effects assume the company-specific differences that are constant over time, the "two-ways" effects assume both "individual" and "time" effects. In other words, the "two-ways" effects imply that differences have been both time-sensitive and company-specific. It is likely that company-specific differences have been timeinvariant (since I look at a relatively short period of time, which is eight years), granting the entrenched nature of Japanese institutions and the resulting incremental change within the local corporate environment. However, it is also possible that changes occurred over time as well, as the proportion of nonregular employees has been increasing from 2010 to 2017 . 
The main regression model used in this research looks as follows:

$$
\begin{gathered}
\text { Nonregular }_{i t}= \\
\alpha_{0}+\alpha_{1} \text { Nonregular }_{i t-1}+\alpha_{2} \log (\text { Director })_{i t}+\alpha_{3} \text { Domestic }_{i t}+\alpha_{4} \text { Foreign }_{i t}+ \\
\alpha_{5} \text { ROA }_{i t}+\alpha_{6} \log (\text { Size })_{i t}+\alpha_{7} \text { AGM } M_{i t}+\alpha_{8} \text { Productivity }_{i t}+\alpha_{9} \text { Tobin's }_{i t}+ \\
\alpha_{10} \text { TSR }_{i t}+\alpha_{11} \text { DOI }_{i t}+\alpha_{12} R \& D_{i t}+\gamma_{i}+\varepsilon_{i t}
\end{gathered}
$$

where Nonregular ${ }_{i t}$ is the ratio of nonregular employees to total employees for the company $i$ at time (year) $t$. $\gamma_{i}$ denotes industry- and firm-specific effects, while $\varepsilon_{i t}$ stands for the residuals or the noise of the model.

Next, I considered applying the linear mixed model (LMM). I chose to test this model for two reasons. First, it is used when the response variable has a non-normal distribution. This holds true for the "Ratio of Nonregulars" dependent variable, which has right-skewed bimodal distribution, as shown above (Figure 6). Second, the LMM allows to account not only for fixed effects (company and industry) but also for random effects within each unit (company) occurring over time (McCulloch, 1996). In other words, the LMM also captures non-independence that exists between time-observations (years 2010-2017) for each individual company. "The random variables of a mixed model add the assumption that observations within a level, the random variable groups, are correlated. Mixed models are designed to address this correlation and do not cause a violation of the independence of observations assumption from the underlying model, e.g. linear or generalized linear" (SSCC, 2016). When comparing $\mathrm{R}^{2}$ of the fixed-effects and LMM models, the latter has a clear advantage (marginal $\mathrm{R}^{2}$ of the LMM is 52 percent, which is almost two times higher than the $\mathrm{R}^{2}$ of the fixed-effects). Moreover, the LMM has a smaller Akaike information criterion (AIC) estimation $(-7,166.45)$ than the fixed-effects model $(-4,489.661)$ which also confirms that the mixed-effects model has a better fit (Table 3 ).

I have conducted the t-test and applied the variance inflation factor (VIF) to make sure that there is no multicollinearity among the explanatory variables. Both procedures showed that there is no such a problem. The results of the t-test that computes pairwise correlations between explanatory variables can be seen from the Table 2.

\subsection{Results and Discussion}

The hypotheses listed in this paper look as follows:

1. Higher levels of SV are associated with higher proportions of nonregular employment.

2.Foreign shareholding is positively correlated with proportions of nonregular employees at Nikkei Index 400 firms.

3.DOI and R\&D are negatively correlated with nonregular employment at Nikkei Index 400 companies. 
The regression coefficients obtained through the application of the LMM model are shown on the Figure 8. Each coefficient demonstrates the change in the response variable (Ratio of Nonregulars) provided we control for other explanatory variables. Excluding the lagged dependent variable, ROA has a highest correlation coefficient with the response variable (0.06), while Productivity, AGM and Total Assets are the only variables with negative coefficients. Among them, only Productivity is significantly correlated with the Ratio of Nonregulars.

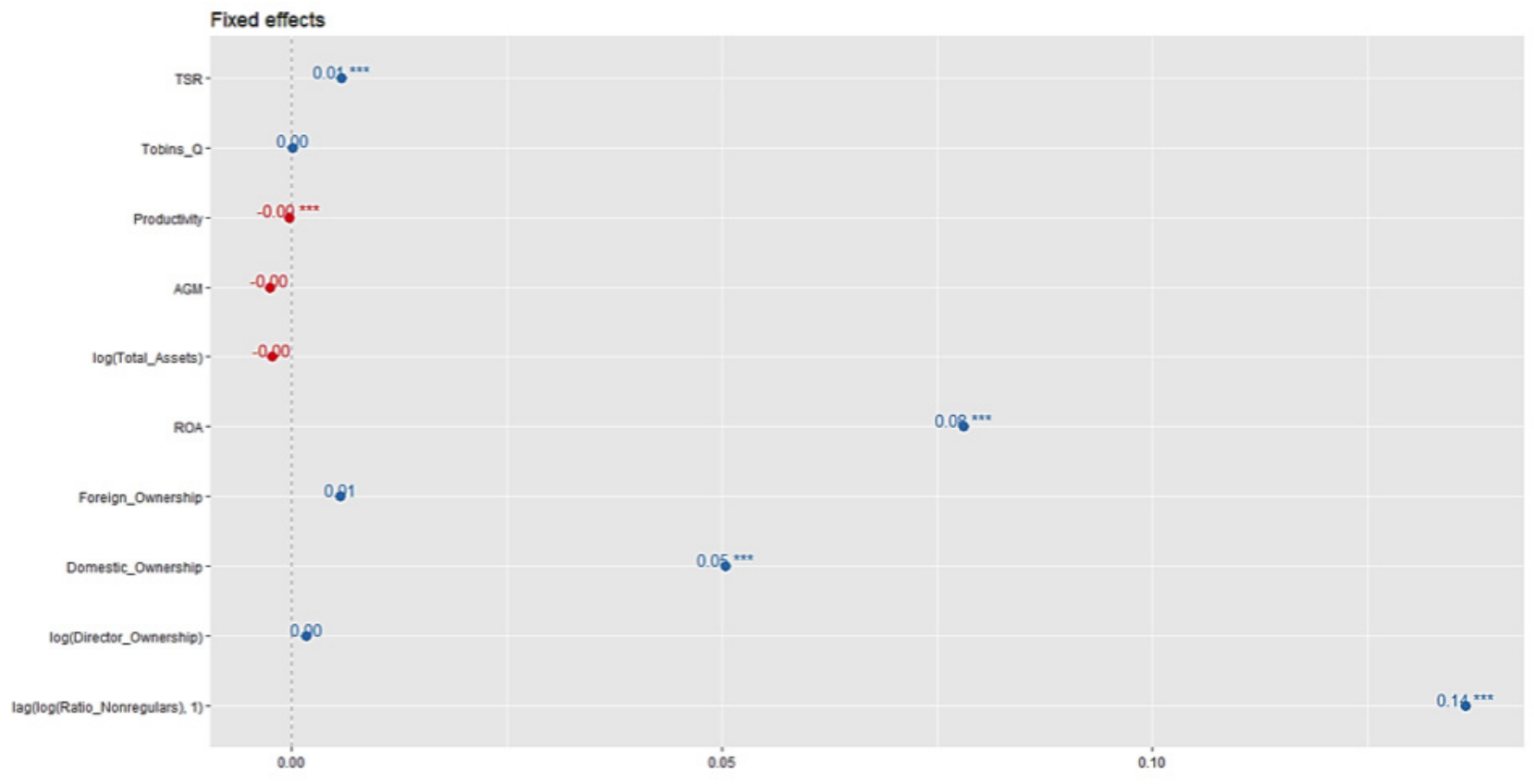

Figure 8. Correlation Coefficients of the LMM

Figure 9 shows the overall fit of the model. The actual quantiles are plotted on the $x$-axis, while the quantiles fitted through a random-effects model are plotted on the $y$-axis. While dots represent observed values, the line exemplifies the linear model called to capture the given distribution. The overall proximity of dots to the line shows the degree the model represents analyzed data. 


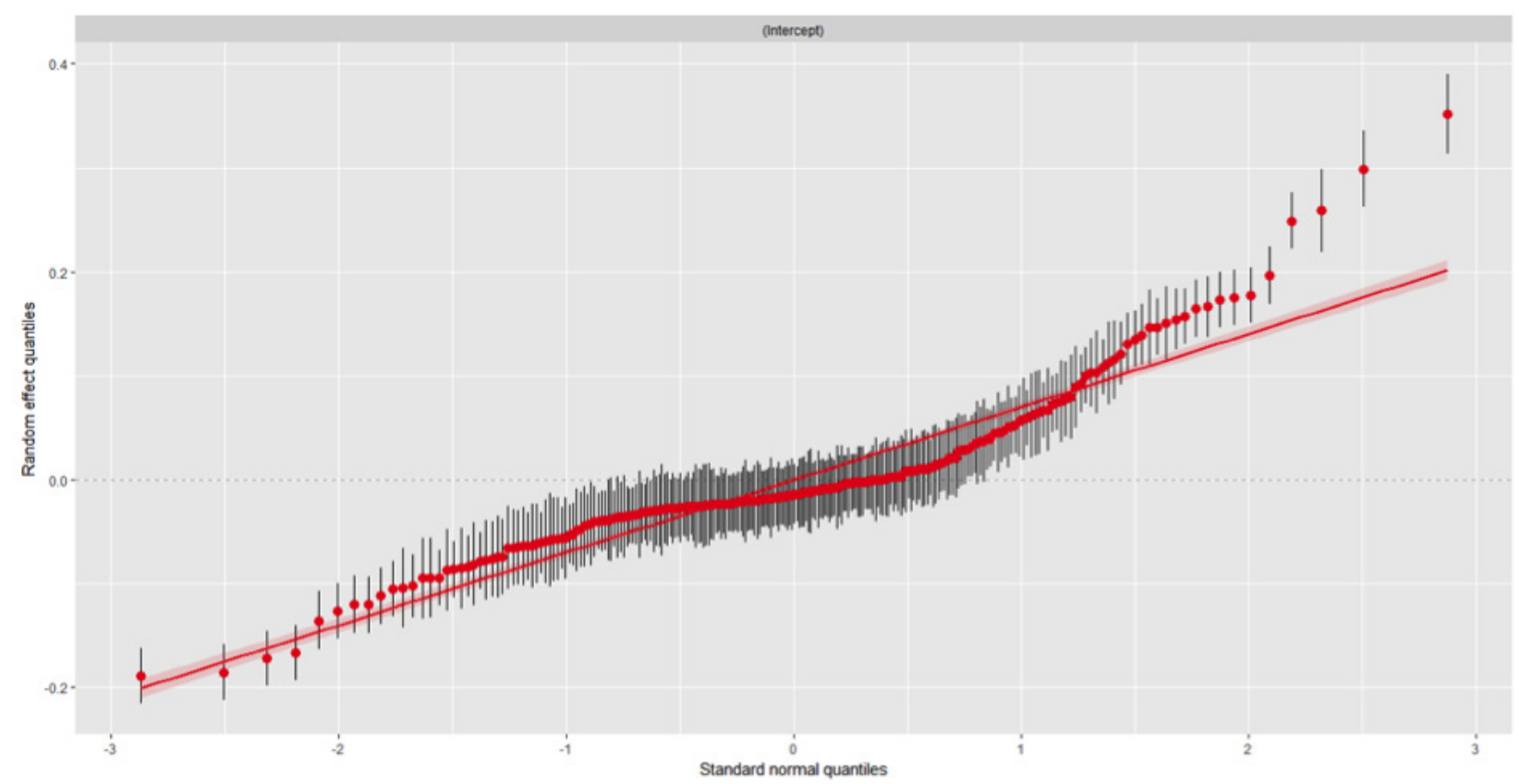

Figure 9. Q-Q Plot for Random Effects

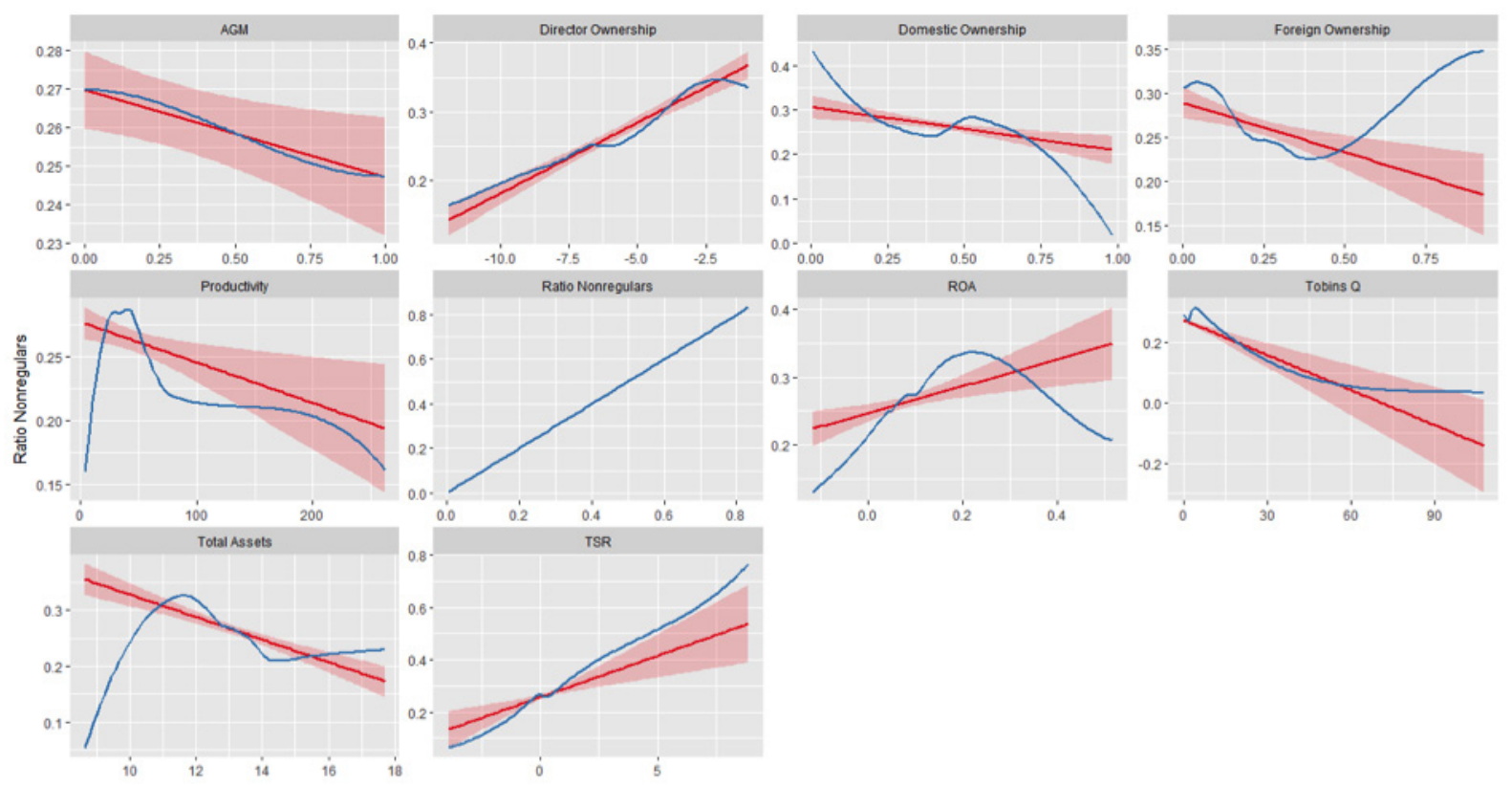

Figure 10. Slopes of Coefficients

Figure 10 demonstrates the relationship between the predictor (red line) and response (blue line) for each explanatory variable. The response is the "Ratio of Nonregulars" that is determined by each of the plotted independent variables within the designed linear regression. Like on the Figure 9, the closer the red line that represents linear model is to the curved distribution of data, the better is the fit. The darker area along the predictor is the 95 percent confidence level interval for predictions from a linear model. 
On one hand, as seen from the Table 6, Tobin's $Q$, which is one of the proxies for shareholder value (SV), does not show significant correlation with the proportion of nonregulars. On the other hand, total shareholder return (TSR) - another SV proxy is positively (0.006) and significantly (at the 0.01 level) correlated with the proportion of nonregular employees. Since the TSR variable indicates stock market fluctuations and dividends per share, it is highly possible, based on the regression results, that higher stock prices and higher dividends are associated with downsizing and cutting of labor costs, primarily via the growing reliance on temporary employees.

Regarding the Hypothesis 2, thus far, the correlation between foreign ownership and nonregular employment is not significant. At the same time, foreign shareholding appears to be correlated with higher profitability measured as ROA $(0.39$, at the 0.01 significance level) and Tobin's $Q(0.001$, at the 0.01 significance level), but lower productivity $(-0.0004$, at the 0.01 significance level) (Table 7 ). This can be interpreted in a following way: increase in foreign shareholding is likely to be associated with higher corporate revenue, but not with higher efficiency of production. The positive correlation between foreign shareholding and profitability is also valid for linear correlation by industry, with the only exception of "Real Estate" (Figure 11).

While there is no significant correlation between foreign ownership and the ratio of nonregulars, such correlation is observed between domestic ownership and the ratio of nonregulars. These variables are positively $(0.05)$ and strongly (at the 0.01 significance level) correlated. This result can be interpreted in a following way. The pertaining institutional compromise between finance, management and regular employees allows core workers to retain their traditional benefits, which comes at price of virtually zero remuneration growth. Ahmadjian \& Robinson (2001) and Ahmadjian \& Robbins (2005) show that companies with higher levels of domestic shareholding are less prone to downsizing. In other words, domestic ownership is associated with stricter adherence to social guarantees for core employees. It also shows stronger managerial influence, since CEOs are protected by insider ownership from potential hostile takeovers (Gospel \& Pendelton, 2003). Most of the large Japanese companies, regardless of their ownership structure, have tended to cut their labor costs during the last three decades to improve their competitiveness. Hence, if a company chooses not to downsize its regular workforce, the only way for it to curb average labor costs is to freeze the hiring of new regulars and to intensify the hiring of nonregulars (Lechevalier et al., 2014). 


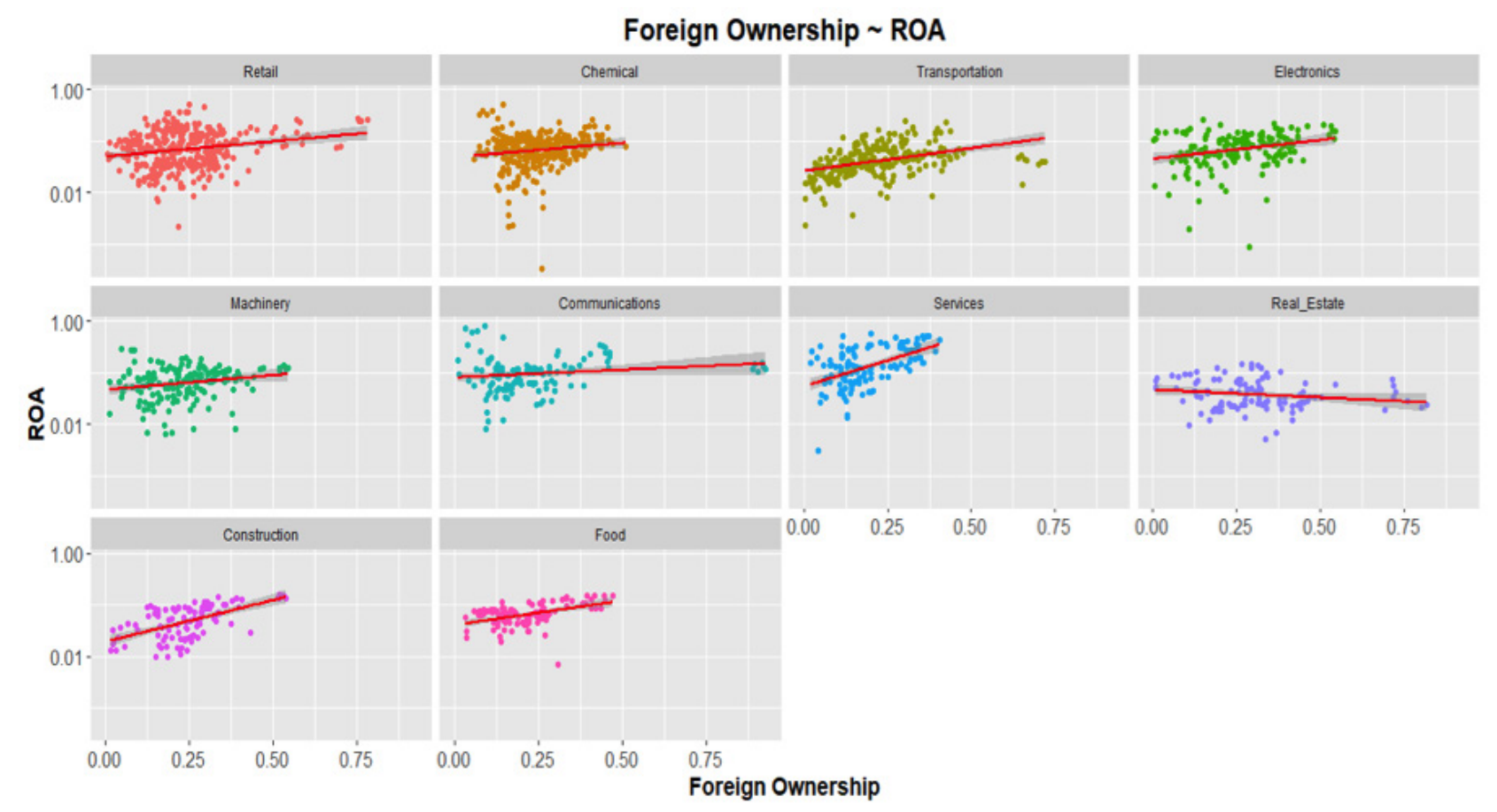

Figure 11. Correlation Between Foreign Ownership and ROA Across Industries

The data on degree of internationalization (DOI) and R\&D intensity required to test the Hypothesis 3 is provided approximately by the half of the analyzed companies: 145 and 140 firms out of 245 disclosed the information regarding their R\&D activity and exports respectively. It can be inferred from the Table 4 that DOI is negatively $(-0.028)$ and significantly (at the 0.01 level) correlated with the Ratio of Nonregulars. This result is in line with the Hypothesis 3. It assumes that companies with higher proportions of overseas sales are the ones less likely to employ higher proportions of temporary employees. This can be due to higher extent of integration into global value chains, which leads to more vigilant supervision of labor standards by international investors. Since nonregular employment in Japan is associated with relatively inferior status and poor social benefits, more internationalized companies are likely to refrain from over-reliance on nonregulars.

As regards the R\&D intensity, Table 6 shows negative $(-0.188)$ and significant (at the 0.01 level) correlation between the R\&D intensity and the Ratio of Nonregulars, which also confirms the Hypothesis 3 . This coefficient can be interpreted in a following way. Firms that invest more in R\&D are overwhelmingly capital-intensive. Hence, they depend less on human resources relatively to labor-intensive industries such as services, retail and food. Since capital-intensive firms have higher entry barrier for their workforce, it is relatively smaller, but, as a rule, composed of more qualified regular employees. On contrary, laborintensive companies invest less and hence, are less dependent on capital. In turn, their profits are associated with control over labor costs that can be curbed by increasing the proportion of nonregular employees.

The panel data analysis yielded some other valuable results. Firstly, ROA shows strong positive correlation with the proportion of nonregulars. It can be corroborated from the positive ( 0.078 ) and significant (at 0.01 level) correlation coefficient. The likely interpretation 
of this correlation is that nonregular employees are instrumental for achieving higher levels of corporate profitability.

On the other hand, these higher profits are not earned in a sustainable way. As seen from the Table 6, productivity is negatively (-0.0004) and significantly (at 0.01 level) related to the proportion of nonregular employees, provided we control for other independent variables. The possible explanation is: the higher is the share of nonregulars at company, the less is the output per employee. This result confirms previous studies (Jones, 2007; Aoyagi \& Ganelli, 2015) that found out that employers are less eager to invest into training of flexible employees. This, in turn, leads to low working motivation among nonregulars as compared to core workers, which explains lower productivity rates for enterprises with higher proportions of nonregular workforce. It can also be inferred from the Figure 12 that the negative linear correlation between the Ratio of Nonregulars and Productivity holds true for all industries except "Communications" and "Electronics".

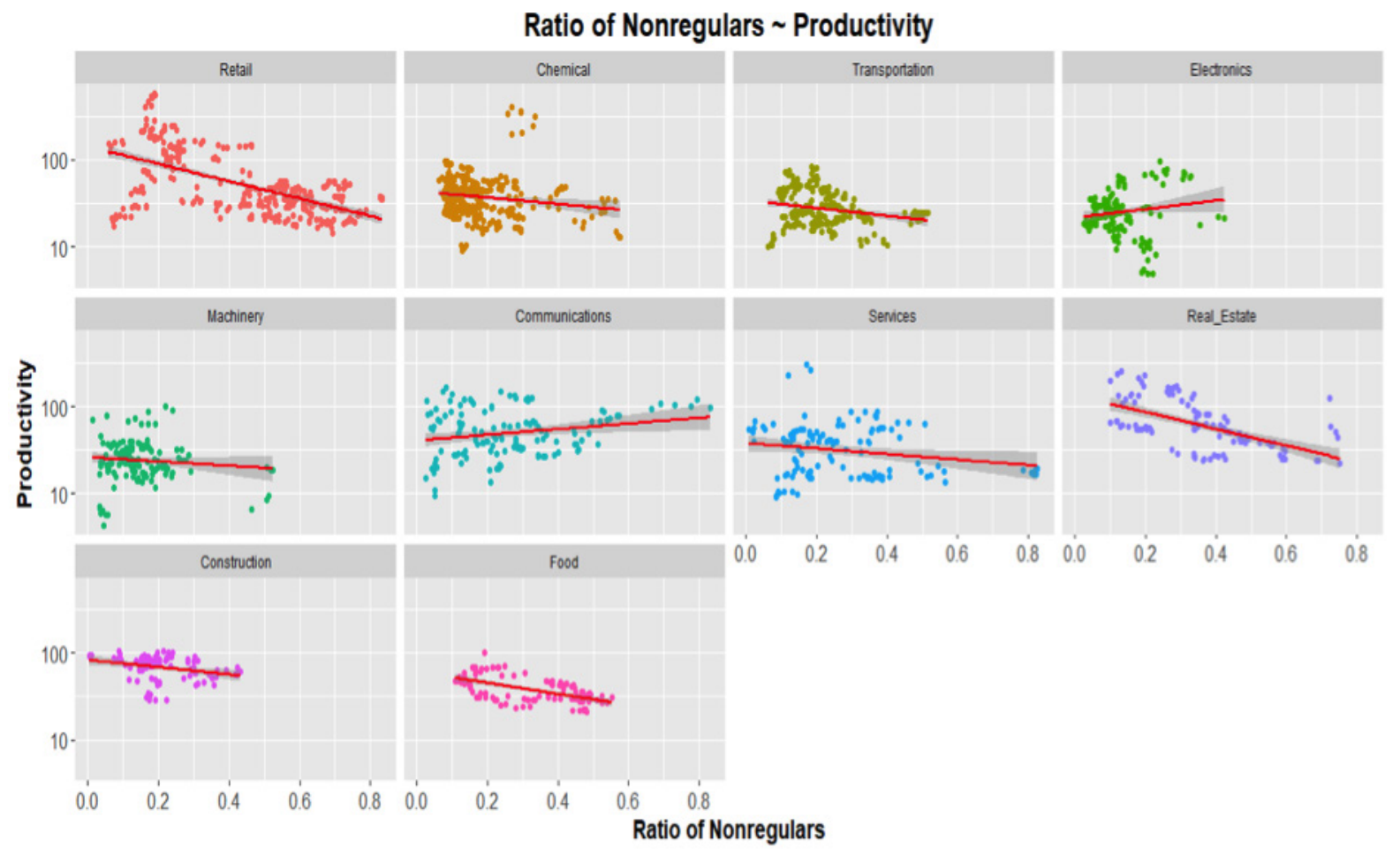

Figure 12. Correlation Between Proportion of Nonregulars and Productivity Across Industries

[Table 1. Descriptive Statistics]

[Table 2. Correlation Matrix]

[Table 3. Panel data analysis for the constituencies of Nikkei Index 400]

[Table 4. Panel data analysis for the constituencies of Nikkei Index 400 (including DOI and R\&D Intensity)]

[Table 5. Panel Data Analysis for JPX-Nikkei Index 400 (Including DOI)]

[Table 6. Panel Data Analysis for JPX-Nikkei Index 400 (Including R\&D Intensity)]

[Table 7. Panel Data Analysis for JPX-Nikkei Index 400 (Foreign Ownership)] 


\section{Conclusions}

This paper has aimed to analyze the effects of the shareholder value pursuit on labor situation at large Japanese listed companies. While the similar studies have highlighted such effects as downsizing and decreased labor costs, this research is novel for its focus on the labor bifurcation, whereby the proportion of nonregular employees has drastically increased. I offer the political economic analysis of Japanese corporate institutions to substantiate the following finding. The increase in the proportion of nonregulars has been reinforced by the recently-formed political economic coalition.

On one hand, the coalition includes outside shareholders as vital providers of capital to Japanese joint-stock companies against the relative decline of debt finance. On the other hand, this political economic bloc insulates managers from direct shareholders' interference and preserves the entrenched alliance between managers and core employees. Thus, current corporate transformations in Japan pursue the strategy of killing two birds with one stone: enhancing the interests of shareholders while preserving institutional integrity.

My article demonstrates that this tactic comes at price of sacrificing the interests of labor. Among others, it is becoming increasingly composed of nonregulars who have minimal chances to become core employees. In a nutshell, the growing proportion of temporary workforce is associated with two factors: higher total shareholder return, which is one of the shareholder value proxies, and domestic ownership, which reflects managerial entrenchment.

\section{Limitations}

First, the presented panel data analysis on nonregular employees does not account for dispatch workers (haken). However, since their number is relatively small (six percent of nonregulars), this should not significantly affect the results of the research.

Second, I only analyze the constituencies of Nikkei Index 400, which are large companies. Hence, my findings might not be generalized for the SMEs as well as unlisted companies.

Third, while I only account for the stock market influence on labor bifurcation, the model is likely to be more accurately explained through the inclusion of capital market variables. For example, international competition certainly affects employers' decision on whether to hire more nonregular employees. Therefore, I do not claim that my independent variables solely explain the increase in temporary employment. In turn, I argue that the shareholder value pursuit is likely to intensify the labor bifurcation at Japanese joint-stock enterprises. 


\section{Annexes}

\begin{tabular}{ccccccccccccc}
\hline \hline Label & $N$ & Missings (\%) & Mean & $S D$ & $S E$ & Median & Trimmed Mean & Min & Max & Range & Skewness & Kurtosis \\
\hline Ratio of Nonregulars & 1848 & 6.48 & 0.26 & 0.18 & 0 & 0.2 & 0.24 & 0.01 & 0.83 & 0.83 & 1.13 & 0.47 \\
Director Ownership & 1938 & 1.92 & 0.03 & 0.07 & 0 & 0 & 0.01 & 0 & 0.54 & 0.54 & 3.27 & 11.57 \\
Domestic Ownership & 1942 & 1.72 & 0.44 & 0.15 & 0 & 0.45 & 0.44 & 0.01 & 0.98 & 0.98 & -0.19 & 0.43 \\
Foreign Ownership & 1939 & 1.87 & 0.24 & 0.13 & 0 & 0.22 & 0.23 & 0 & 0.93 & 0.93 & 1.2 & 3.44 \\
ROA & 1917 & 2.99 & 0.08 & 0.07 & 0 & 0.07 & 0.07 & -0.12 & 0.57 & 0.68 & 2.43 & 9.55 \\
Total Assets & 1927 & 2.48 & 1615144.48 & 3678650.55 & 83800.71 & 512365 & 835033.09 & 5741 & 48750186 & 48744445 & 6.58 & 60.14 \\
AGM & 1939 & 1.87 & 0.29 & 0.45 & 0.01 & 0 & 0.24 & 0 & 1 & 1 & 0.91 & -1.17 \\
Productivity & 1820 & 7.89 & 45.56 & 36.93 & 0.87 & 33.84 & 38.4 & 4.09 & 261.9 & 257.81 & 2.6 & 8.4 \\
Tobin's Q & 1901 & 3.8 & 3.1 & 5.69 & 0.13 & 1.4 & 1.76 & 0 & 107.59 & 107.59 & 6.65 & 78.42 \\
TSR & 1958 & 0.91 & 0.19 & 0.51 & 0.01 & 0.1 & 0.13 & -3.91 & 8.89 & 12.81 & 5.3 & 68.11 \\
Internationalization & 940 & 52.43 & 0.47 & 0.23 & 0.01 & 0.47 & 0.47 & 0 & 0.98 & 0.97 & 0 & -0.95 \\
R\&D Intensity & 1128 & 42.91 & 0.03 & 0.04 & 0 & 0.03 & 0.03 & 0 & 0.3 & 0.3 & 2.52 & 8.39 \\
\hline
\end{tabular}

Table 1. Descriptive Statistics 


\begin{tabular}{|c|c|c|c|c|c|c|c|c|c|c|c|c|}
\hline & $\begin{array}{c}\text { Ratio of } \\
\text { Nonregulars }\end{array}$ & $\begin{array}{l}\text { Director } \\
\text { Ownership }\end{array}$ & $\begin{array}{l}\text { Domestic } \\
\text { Ownership }\end{array}$ & $\begin{array}{c}\text { Foreign } \\
\text { Ownership }\end{array}$ & $R O A$ & $\begin{array}{l}\text { Total } \\
\text { Assets }\end{array}$ & $A G M$ & Productivity & $\begin{array}{c}\text { Tobin's } \\
Q\end{array}$ & $T S R$ & Internationalization & $\begin{array}{c}R \& D \\
\text { Intensity }\end{array}$ \\
\hline $\begin{array}{l}\text { Ratio of } \\
\text { Nonregulars }\end{array}$ & & $0.150^{* * 8}$ & $-0.074^{* *}$ & $-0.069^{* *}$ & $0.069^{* *}$ & $-0.088^{* * *}$ & $-0.060^{*}$ & $-0.071^{* *}$ & $-0.120^{* * *}$ & $0.077^{* * 8}$ & $-0.327^{* * *}$ & $-0.287^{* * *}$ \\
\hline Director Ownership & $0.150^{* * *}$ & & $-0.542^{* * *}$ & $-0.197^{* * *}$ & $0.448^{* * *}$ & $-0.128^{* * *}$ & $-0.064^{* *}$ & -0.039 & $0.056^{*}$ & $0.061^{* *}$ & $-0.169^{* * *}$ & -0.027 \\
\hline $\begin{array}{l}\text { Domestic } \\
\text { Ownership }\end{array}$ & $-0.074^{* *}$ & $-0.542^{* * *}$ & & $-0.368^{* * *}$ & $-0.252^{* * *}$ & $-0.049^{*}$ & 0.008 & -0.035 & -0.026 & -0.028 & 0.026 & 0.032 \\
\hline Foreign Ownership & $-0.069^{* *}$ & $-0.197^{* * *}$ & $-0.368^{* * *}$ & & $0.157^{* * 8}$ & $0.174^{* * *}$ & $-0.046^{*}$ & $0.099^{* * 8}$ & $0.097^{8 * *}$ & -0.032 & $0.336^{* * 8}$ & -0.016 \\
\hline$R O A$ & $0.069^{* *}$ & $0.448^{* * *}$ & $-0.252^{* * *}$ & $0.157^{* * *}$ & & $-0.177^{* * *}$ & $-0.121^{* * *}$ & -0.037 & $0.229^{* * *}$ & $0.063^{* *}$ & $0.176^{* * *}$ & 0.008 \\
\hline Total Assets & $-0.088^{* * *}$ & $-0.128^{* * *}$ & $-0.049^{*}$ & $0.174^{* * *}$ & $-0.177^{* * *}$ & & -0.018 & $0.177^{* * *}$ & $-0.090^{* * *}$ & $-0.048^{*}$ & $0.162^{* * *}$ & -0.024 \\
\hline$A G M$ & $-0.060^{*}$ & $-0.064^{* *}$ & 0.008 & $-0.046^{*}$ & $-0.121^{* * *}$ & -0.018 & & 0.011 & -0.015 & -0.016 & $-0.093^{* *}$ & -0.049 \\
\hline Productivity & $-0.071^{* *}$ & -0.039 & -0.035 & $0.099^{* * *}$ & -0.037 & $0.177^{* * *}$ & 0.011 & & $-0.134^{* * *}$ & -0.009 & $-0.143^{* * *}$ & $-0.244^{* * *}$ \\
\hline Tobin's $Q$ & $-0.120^{* * *}$ & $0.056^{*}$ & -0.026 & $0.097^{* * *}$ & $0.229^{* * *}$ & $-0.090^{* * *}$ & -0.015 & $-0.134^{* * *}$ & & $-0.046^{*}$ & $0.261^{* * *}$ & $0.219^{* * *}$ \\
\hline$T S R$ & $0.077^{* * *}$ & $0.061^{* *}$ & -0.028 & -0.032 & $0.063^{* *}$ & $-0.048^{*}$ & -0.016 & -0.009 & $-0.046^{*}$ & & 0.000 & 0.014 \\
\hline Internationalization & $-0.327^{* * *}$ & $-0.169^{* * *}$ & 0.026 & $0.336^{* * *}$ & $0.176^{* * 8}$ & $0.162^{* * *}$ & $-0.093^{* *}$ & $-0.143^{* * *}$ & $0.261^{* * *}$ & 0.000 & & $0.261^{* * *}$ \\
\hline$R \& D$ Intensity & $-0.287^{* * *}$ & -0.027 & 0.032 & -0.016 & 0.008 & -0.024 & -0.049 & $-0.244^{* * *}$ & $0.219^{* * *}$ & 0.014 & $0.261^{* * *}$ & \\
\hline
\end{tabular}

Table 2. Correlation Matrix 
Panel Data Analysis for JPX-Nikkei Index 400

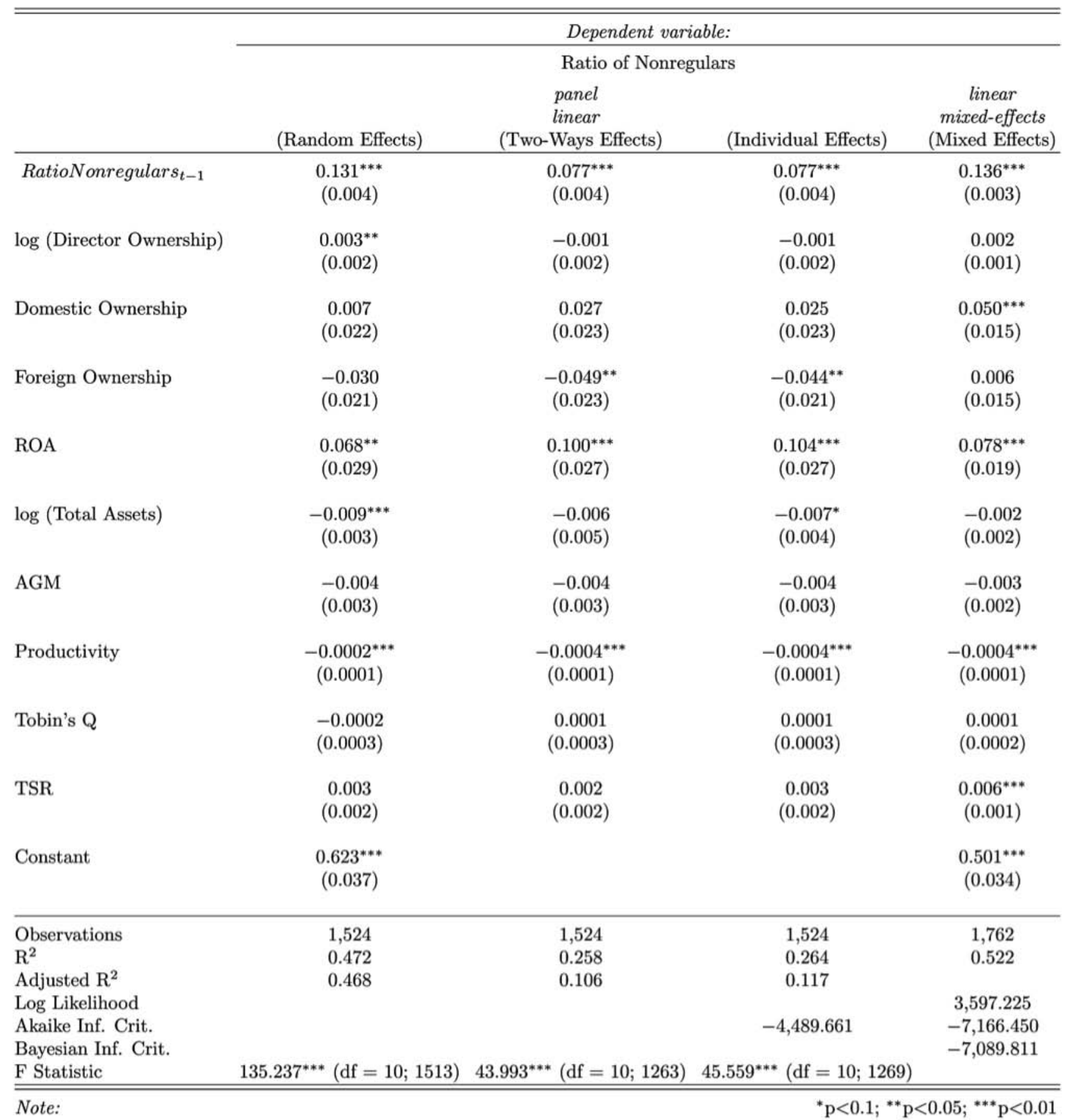

Table 3. Panel data analysis for the constituencies of Nikkei Index 400 
Panel Data Analysis for JPX-Nikkei Index 400 (Including DOI and R\&D Intensity)

\begin{tabular}{|c|c|c|c|c|}
\hline & \multicolumn{4}{|c|}{ Dependent variable: } \\
\hline & (Random Effects) & $\begin{array}{c}\text { Ratio of Nonre } \\
\text { panel } \\
\text { linear } \\
\text { (Two-Ways Effects) }\end{array}$ & (Individual Effects) & $\begin{array}{c}\text { linear } \\
\text { mixed-effects } \\
\text { (Mixed Effects) }\end{array}$ \\
\hline RatioNonregulars $_{t-1}$ & $\begin{array}{c}0.116^{* * *} \\
(0.004)\end{array}$ & $\begin{array}{c}0.078^{* * *} \\
(0.006)\end{array}$ & $\begin{array}{c}0.081^{* * *} \\
(0.006)\end{array}$ & $\begin{array}{c}0.134^{* * *} \\
(0.003)\end{array}$ \\
\hline $\log$ (Director Ownership) & $\begin{array}{c}-0.0005 \\
(0.002)\end{array}$ & $\begin{array}{l}-0.004 \\
(0.002)\end{array}$ & $\begin{array}{l}-0.004 \\
(0.002)\end{array}$ & $\begin{array}{l}-0.001 \\
(0.001)\end{array}$ \\
\hline Domestic Ownership & $\begin{array}{c}-0.039 \\
(0.025)\end{array}$ & $\begin{array}{c}-0.020 \\
(0.033)\end{array}$ & $\begin{array}{l}-0.025 \\
(0.033)\end{array}$ & $\begin{array}{c}0.006 \\
(0.016)\end{array}$ \\
\hline Foreign Ownership & $\begin{array}{l}-0.042 \\
(0.026)\end{array}$ & $\begin{array}{c}-0.013 \\
(0.034)\end{array}$ & $\begin{array}{l}-0.033 \\
(0.032)\end{array}$ & $\begin{array}{c}0.019 \\
(0.016)\end{array}$ \\
\hline ROA & $\begin{array}{c}0.134^{* * *} \\
(0.043)\end{array}$ & $\begin{array}{c}0.121^{* * *} \\
(0.044)\end{array}$ & $\begin{array}{l}0.112^{* *} \\
(0.045)\end{array}$ & $\begin{array}{c}-0.038^{*} \\
(0.022)\end{array}$ \\
\hline $\log$ (Total Assets) & $\begin{array}{c}-0.008^{* *} \\
(0.003)\end{array}$ & $\begin{array}{c}0.004 \\
(0.011)\end{array}$ & $\begin{array}{c}-0.018^{* *} \\
(0.009)\end{array}$ & $\begin{array}{c}-0.006^{* *} \\
(0.003)\end{array}$ \\
\hline AGM & $\begin{array}{r}-0.001 \\
(0.004)\end{array}$ & $\begin{array}{l}0.0004 \\
(0.005)\end{array}$ & $\begin{array}{c}0.002 \\
(0.005)\end{array}$ & $\begin{array}{l}-0.001 \\
(0.002)\end{array}$ \\
\hline Productivity & $\begin{array}{l}-0.0001 \\
(0.0001)\end{array}$ & $\begin{array}{l}0.00001 \\
(0.0002)\end{array}$ & $\begin{array}{l}-0.00003 \\
(0.0002)\end{array}$ & $\begin{array}{c}0.0001 \\
(0.0001)\end{array}$ \\
\hline Tobin's Q & $\begin{array}{l}-0.0001 \\
(0.0003)\end{array}$ & $\begin{array}{c}-0.00002 \\
(0.0003)\end{array}$ & $\begin{array}{l}0.00003 \\
(0.0003)\end{array}$ & $\begin{array}{c}0.0001 \\
(0.0001)\end{array}$ \\
\hline TSR & $\begin{array}{l}-0.003 \\
(0.003)\end{array}$ & $\begin{array}{l}-0.001 \\
(0.003)\end{array}$ & $\begin{array}{l}-0.002 \\
(0.003)\end{array}$ & $\begin{array}{c}0.001 \\
(0.001)\end{array}$ \\
\hline DOI & $\begin{array}{c}-0.054^{* * *} \\
(0.014)\end{array}$ & $\begin{array}{c}0.001 \\
(0.025)\end{array}$ & $\begin{array}{l}-0.028 \\
(0.024)\end{array}$ & $\begin{array}{l}-0.015 \\
(0.010)\end{array}$ \\
\hline R\&D Intensity & $\begin{array}{c}-0.225^{* * *} \\
(0.085)\end{array}$ & $\begin{array}{c}0.002 \\
(0.152)\end{array}$ & $\begin{array}{l}-0.052 \\
(0.149)\end{array}$ & $\begin{array}{c}-0.154^{* * *} \\
(0.057)\end{array}$ \\
\hline Constant & $\begin{array}{c}0.559^{* * *} \\
(0.042)\end{array}$ & & & $\begin{array}{c}0.512^{* * *} \\
(0.035)\end{array}$ \\
\hline Observations & 664 & 664 & 664 & 763 \\
\hline $\mathrm{R}^{2}$ & 0.562 & 0.295 & 0.302 & 0.739 \\
\hline Adjusted $\mathrm{R}^{2}$ & 0.554 & 0.124 & 0.143 & \\
\hline $\begin{array}{l}\text { Log Likelihood } \\
\text { Akaike Inf. Crit. }\end{array}$ & & & & $\begin{array}{c}1,875.977 \\
-3,719.954\end{array}$ \\
\hline Bayesian Inf. Crit. & & & & $-3,645.758$ \\
\hline F Statistic & $69.691^{* * *}(\mathrm{df}=12 ; 651)$ & $18.587^{* * *}(\mathrm{df}=12 ; 534)$ & $19.465^{* * *}(\mathrm{df}=12 ; 540)$ & \\
\hline
\end{tabular}

Table 4. Panel Data Analysis for JPX-Nikkei Index 400 (Including DOI and R\&D Intensity) 
Panel Data Analysis for JPX-Nikkei Index 400 (Including DOI)

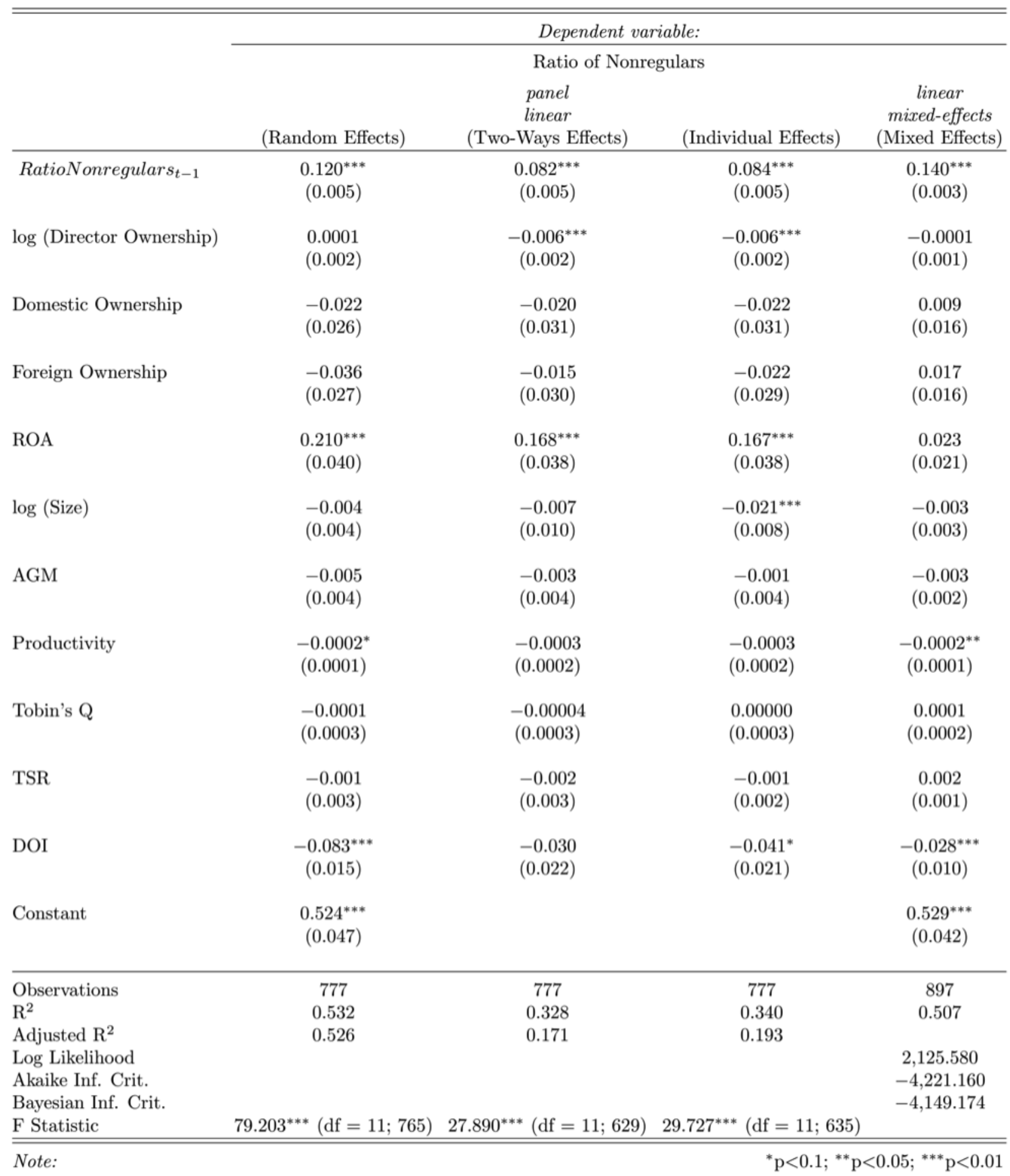

Table 5. Panel Data Analysis for JPX-Nikkei Index 400 (Including DOI) 
Panel Data Analysis for JPX-Nikkei Index 400 (Including R\&D Intensity)

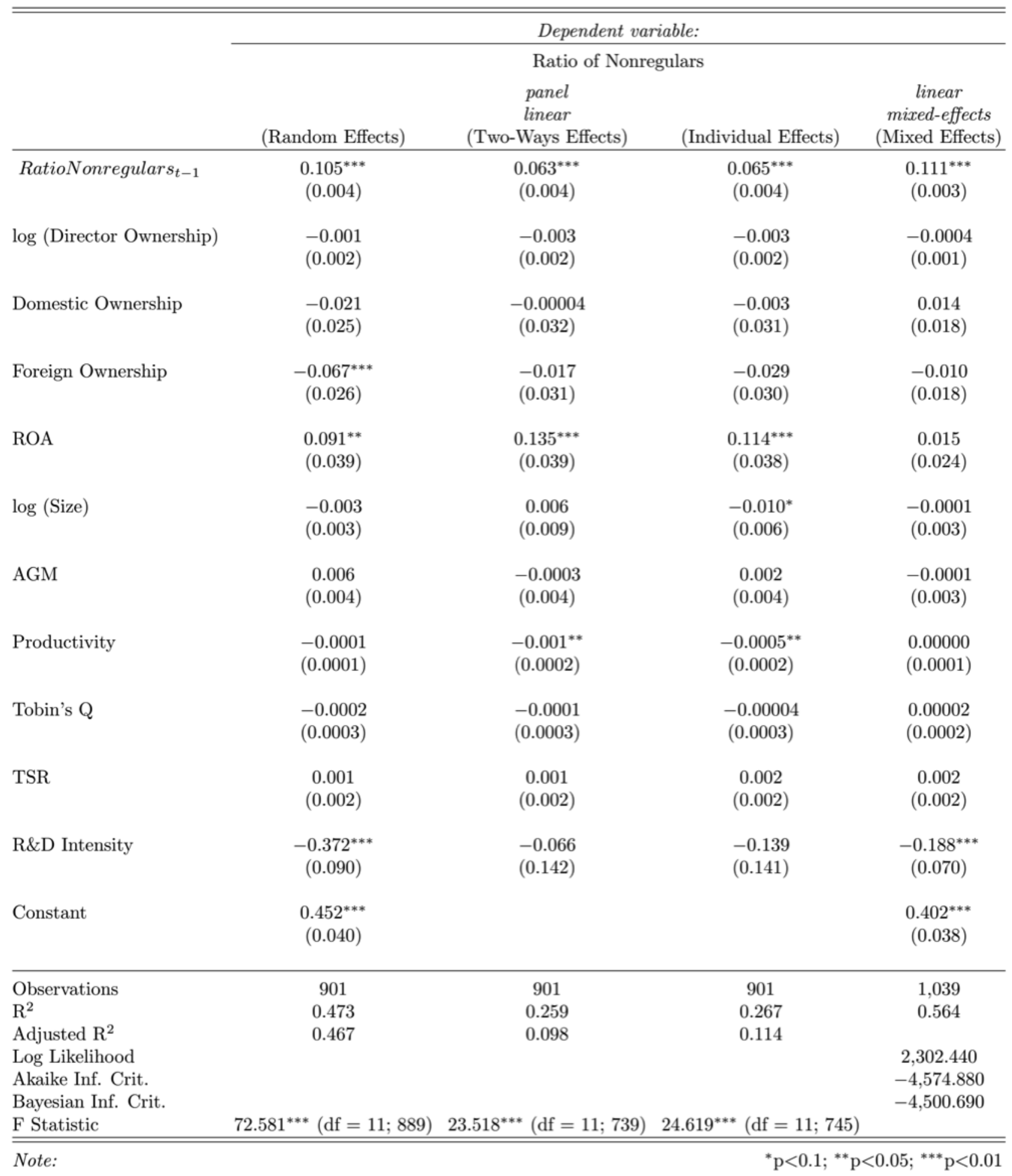

Table 6. Panel Data Analysis for JPX-Nikkei Index 400 (Including R\&D Intensity) 
Panel Data Analysis for JPX-Nikkei Index 400 (Foreign Ownership)

\begin{tabular}{|c|c|c|c|c|}
\hline & \multicolumn{4}{|c|}{ Dependent variable: } \\
\hline & \multicolumn{4}{|c|}{ Foreign Ownership } \\
\hline & (Random Effects) & $\begin{array}{c}\text { panel } \\
\text { linear } \\
\text { (Two-Ways Effects) } \\
\end{array}$ & (Individual Effects) & $\begin{array}{c}\text { linear } \\
\text { mixed-effects } \\
\text { (Mixed Effects) } \\
\end{array}$ \\
\hline $\log$ (Director Ownership) & $\begin{array}{c}-0.019^{* * *} \\
(0.002)\end{array}$ & $\begin{array}{c}-0.018^{* * *} \\
(0.002)\end{array}$ & $\begin{array}{c}-0.022^{* * *} \\
(0.002)\end{array}$ & $\begin{array}{c}-0.020^{* * *} \\
(0.002)\end{array}$ \\
\hline Domestic Ownership & $\begin{array}{c}-0.359^{* * *} \\
(0.022)\end{array}$ & $\begin{array}{c}-0.289^{* * *} \\
(0.023)\end{array}$ & $\begin{array}{c}-0.338^{* * *} \\
(0.024)\end{array}$ & $\begin{array}{c}-0.353^{* * *} \\
(0.022)\end{array}$ \\
\hline Ratio of Nonregulars & $\begin{array}{c}0.016 \\
(0.022)\end{array}$ & $\begin{array}{c}0.002 \\
(0.026)\end{array}$ & $\begin{array}{c}0.004 \\
(0.027)\end{array}$ & $\begin{array}{c}-0.0003 \\
(0.024)\end{array}$ \\
\hline ROA & $\begin{array}{c}0.388^{* * *} \\
(0.029)\end{array}$ & $\begin{array}{c}0.266^{* * *} \\
(0.029)\end{array}$ & $\begin{array}{c}0.335^{* * *} \\
(0.030)\end{array}$ & $\begin{array}{c}0.390^{* * * *} \\
(0.029)\end{array}$ \\
\hline $\log$ (Total Assets) & $\begin{array}{c}0.050^{* * *} \\
(0.003)\end{array}$ & $\begin{array}{c}0.025^{* * *} \\
(0.006)\end{array}$ & $\begin{array}{c}0.077^{* * *} \\
(0.004)\end{array}$ & $\begin{array}{c}0.055^{* * *} \\
(0.003)\end{array}$ \\
\hline AGM & $\begin{array}{l}-0.004 \\
(0.004)\end{array}$ & $\begin{array}{c}0.001 \\
(0.003)\end{array}$ & $\begin{array}{l}-0.002 \\
(0.004)\end{array}$ & $\begin{array}{l}-0.004 \\
(0.004)\end{array}$ \\
\hline Productivity & $\begin{array}{c}-0.0003^{* * *} \\
(0.0001)\end{array}$ & $\begin{array}{c}-0.0003^{* *} \\
(0.0001)\end{array}$ & $\begin{array}{c}-0.0004^{* * *} \\
(0.0001)\end{array}$ & $\begin{array}{c}-0.0004^{* * *} \\
(0.0001)\end{array}$ \\
\hline Tobin's Q & $\begin{array}{l}0.001^{* * *} \\
(0.0003)\end{array}$ & $\begin{array}{l}0.001^{* *} \\
(0.0003)\end{array}$ & $\begin{array}{l}0.001^{* *} \\
(0.0003)\end{array}$ & $\begin{array}{l}0.001^{* * *} \\
(0.0003)\end{array}$ \\
\hline TSR & $\begin{array}{c}-0.004^{*} \\
(0.002)\end{array}$ & $\begin{array}{c}-0.004^{* *} \\
(0.002)\end{array}$ & $\begin{array}{c}-0.005^{* *} \\
(0.002)\end{array}$ & $\begin{array}{c}-0.004^{* *} \\
(0.002)\end{array}$ \\
\hline Constant & $\begin{array}{c}-0.402^{* * *} \\
(0.043)\end{array}$ & & & $\begin{array}{c}-0.465^{* * *} \\
(0.046)\end{array}$ \\
\hline Observations & 1,762 & 1,762 & 1,762 & 1,762 \\
\hline $\mathrm{R}^{2}$ & 0.372 & 0.191 & 0.413 & 0.412 \\
\hline Adjusted $\mathrm{R}^{2}$ & 0.369 & 0.051 & 0.315 & \\
\hline Log Likelihood & & & & $2,780.763$ \\
\hline Akaike Inf. Crit. & & & & $-5,535.526$ \\
\hline Bayesian Inf. Crit. & & & & $-5,464.361$ \\
\hline F Statistic & $115.489^{* * *}(\mathrm{df}=9 ; 1752)$ & $39.374^{* * *}(\mathrm{df}=9 ; 1501)$ & $118.053^{* * *}(\mathrm{df}=9 ; 1508)$ & \\
\hline
\end{tabular}

Table 7. Panel Data Analysis for JPX-Nikkei Index 400 (Foreign Ownership) 


\section{List of Figures and Tables}

Figure 1. Proportion of Regular and Nonregular Employees. Source: Labour Force Survey (2017)

Figure 2. Types of Nonregular Employment. Source: Labour Force Survey (2017) p. 6

Figure 3. Distribution Percent of Market Value Owned by Type of Shareholder. Source: Tokyo Stock Shareownership Survey (2017)

p. 11

Figure 4. Distribution of Nonregulars Across Industries $\quad$ p. 14

Figure 5. Average Yearly Ratios of Nonregulars $\quad$ p. 14

Figure 6. Density Plot for the Ratio of Nonregulars $\quad$ p. 15

Figure 7. Density Plot for the Ratio of Nonregulars by Industry p. 15

$\begin{array}{ll}\text { Figure 8. Correlation Coefficients of the LMM } & \text { p. } 18\end{array}$

$\begin{array}{ll}\text { Figure 10. Slopes of Coefficients } & \text { p. } 19\end{array}$

Figure 11. Correlation Between Foreign Ownership and ROA Across Industries p. 20

Figure 12. Correlation Between Proportion of Nonregulars and Productivity Across Industries

p. 22

$\begin{array}{ll}\text { Table 1. Descriptive Statistics } & \text { p. } 24\end{array}$

$\begin{array}{ll}\text { Table 2. Correlation Matrix } & \text { p. } 25\end{array}$

Table 3. Panel data analysis for the constituencies of Nikkei Index $400 \quad$ p. 26

Table 4. Panel Data Analysis for JPX-Nikkei Index 400 (Including DOI and R\&D Intensity)

Table 5. Panel Data Analysis for JPX-Nikkei Index 400 (Including DOI) p. 28

Table 6. Panel Data Analysis for JPX-Nikkei Index 400 (Including R\&D Intensity) p. 29

Table 7. Panel Data Analysis for JPX-Nikkei Index 400 (Foreign Ownership) p. 30 


\section{References}

Abe, M. \& Hoshi, T. (2007). Corporate finance and human resource management in Japan. In M. Aoki, G. Jackson \& H. Miyajima (Eds.), Corporate governance in Japan. Institutional Change and Organizational Diversity. Oxford, New York: Oxford University Press.

Abe, N., \& Shimizutani, S. (2007). Employment policy and corporate governance-An empirical comparison of the stakeholder and the profit-maximization model. Journal of Comparative Economics, 35(2), 346-368.

Aglietta, M. (2000). Shareholder value and corporate governance: some tricky questions. In Economy and Society 29 (1), pp. 146-159.

Ahmadjian, C. L. \& Robbins, G. E. (2005). A clash of capitalisms: Foreign shareholders and corporate restructuring in 1990s Japan. In American Sociological Review 70 (3), pp. 451-471.

Ahmadjian, C. L., \& Robinson, P. (2001). Safety in numbers: Downsizing and the deinstitutionalization of permanent employment in Japan. Administrative Science Quarterly, 46(4), 622-654.

Amable, B. (2016). Institutional complementarities in the dynamic comparative analysis of capitalism. In Journal of Institutional Economics 12 (01), pp. 79-103.

Amable, B., Ernst, E. \& Palombarini, S. (2005). How do financial markets affect industrial relations: an institutional complementarity approach. Socio-Economic Review, 3(2), pp.311-330.

Aoki, M. (1994). The contingent governance of teams: Analysis of institutional complementarity. International Economic Review, pp. 657-676.

Aoyagi, C. \& Ganelli, G. (2015). Labor Market Reform: Vital to the Success of Abenomics. In Botman, D., Danninger, S. \& Schiff, J. (Eds.), Can Abenomics Succeed, International Monetary Fund, Business \& Economics, 201 pages.

Bates, D., Maechler, M., Bolker, B \& Walker, S. (2015). Fitting Linear Mixed-Effects Models Using Ime4. Journal of Statistical Software, 67(1), 1-48.

Conrad, H. (2009). From seniority to performance principle: The evolution of pay practices in Japanese firms since the 1990s. Social Science Japan Journal, 13(1), pp.115135.

Croissant, Y., \& Millo, G. (2008). Panel data econometrics in R: The plm package. Journal of Statistical Software, 27(2), 1-43.

Crouch, C., Streeck, W., Boyer, R., Amable, B., Hall, P.A. \& Jackson, G. (2005). Dialogue on 'Institutional complementarity and political economy'. Socio-Economic Review, 3(2), pp.359-382. 
Darcillon, T. (2015). How does finance affect labor market institutions? An empirical analysis in 16 OECD countries. In Socioeconomic Review 13 (3), pp. 477-504.

Deakin, S. (2005). The coming transformation of shareholder value. Corporate Governance: An International Review, 13(1), 11-18.

Dobbs, R. \& Koller, T. (2005). Measuring stock market performance. McKinsey Finance, 17(5), pp.1-4.

Dore, R. (2007). Shareholder capitalism comes to Japan. In Zeitschrift für Japanisches Recht 12 (23), pp. 207-214.

Dore, R. (2008). Financialization of the Global Economy. In Industrial and Corporate Change 17 (6), pp. 1097-1112.

Fiss, P. C., \& Zajac, E. J. (2004). The diffusion of ideas over contested terrain: The (non) adoption of a shareholder value orientation among German firms. Administrative Science Quarterly, 49(4), 501-534.

Friedman, M. (1970). The Social Responsibility of Business is to Increase its Profits. New York Times Magazine, 13, 32-33.

Gordon, A. (2017). New and Enduring Dual Structures of Employment in Japan: The Rise of Non-Regular Labor, 1980s-2010s. Social Science Japan Journal, 20(1), pp.9-36.

Gospel, H., \& Pendleton, A. (2003). Finance, corporate governance and the management of labour: A conceptual and comparative analysis. British Journal of Industrial Relations, 41(3), 557-582.

Hlavac, M. (2018). stargazer: Well-Formatted Regression and Summary Statistics Tables. Bratislava, Slovakia. Retrieved from https://CRAN.R-project.org/package=stargazer

Höpner, M. (2005). What connects industrial relations and corporate governance? Explaining institutional complementarity. Socio-Economic Review, 3(2), pp.331-358.

Inagami, T., \& Whittaker, D. H. (2005). The new community firm: Employment, governance and management reform in Japan. Cambridge University Press.

Ito, K. (2014). Review of Competitiveness and Incentives for Sustainable Growth. Final Report.

Jackson, G. (2007). 'Employment Adjustment and Distributional Conflict' in M. Aoki, G. Jackson \& H. Miyajima (Eds.), Corporate governance in Japan. Institutional Change and Organizational Diversity. Oxford, New York: Oxford University Press.

Jackson, G. (2016). Toward a Conceptual Framework for Understanding Institutional Change in Japanese Capitalism: Structural Transformations and Organizational Diversity. INCAS Project. European Commission's H2020 Programme. 
Jacoby, S. M. (2005). The Embedded Corporation: Corporate Governance and Employment Relations in Japan and the United States. Princeton: Princeton University Press.

Japan Revitalization Strategy (2013). Japan's Challenge for Future.

Japan Statistical Yearbook (2017). Ministry of Internal Affairs and Communications of Japan.

Jensen, M. C. \&Meckling, W. H. (1976). Theory of the firm: Managerial behavior, agency costs and ownership structure. Journal of financial economics, 3(4), 305-360.

Jones, R. (2007). Income Inequality, Poverty and Social Spending in Japan. OECD Economics Department Working Papers, No. 556, OECD Publishing, Paris.

JPX (2017). Voluntary Application of IFRS (Current and scheduled). Japan Exchange Group.

JPX-Index Nikkei 400 Guidebook. (2016).

Jürgens, U., Naumann, K., \& Rupp, J. (2000). Shareholder Value in an Adverse Environment: The German case. In Economy and Society 29 (1), pp. 54-79.

Labour Force Survey (2017). Historical Data 9. Ministry of Internal Affairs and Communications of Japan.

Lechevalier, S., Dossougoin, C., Hurlin, C., \& Takaoka, S. (2014). How did the Japanese Employment System Change? Investigating the Heterogeneity of Downsizing Practices across Firms (No. 883). Kyoto University, Institute of Economic Research.

Lechevalier, S., Debanes, P. \& Shin, W. (2016). Financialization and industrial policies in Japan and Korea: Evolving complementarities and loss of institutional capabilities. Discussion Paper Series 2016 \#01. Working paper on INCAS blog

Lüdecke, D. (2018)._sjmisc: Miscellaneous Data Management Tools_. R package version 2.7.0.

Lüdecke D (2018b)._sjPlot: Data Visualization for Statistics in Social Science_. R package version 2.4.1.

McCulloch, C. E. (1996). An introduction to generalized linear mixed models.

Milhaupt, C. J. (2017). Evaluating Abe's Third Arrow: How Significant are Japan's Recent Corporate Governance Reforms? Columbia Law and Economics. Working Paper No. 561.

Ministry of Health, Labour and Welfare. (2015). Outline of Health, Labour and Welfare Statistics. 厚生労働省, 2015. 厚生労働統計のあらまし.

Ministry of Health, Labour and Welfare. (2016). Analysis of Labour Economy. 厚生労 働省, 2016. 労働経済の分析. 
Mitchell, R., O'Donnell, A., \& Ramsay, I. (2005). Shareholder value and employee interests: intersections between corporate governance, corporate law and labor law. Wis. Int'l LJ, 23, 417.

Miyamoto, M. (2017). Change and continuity in Japanese corporate reform. In Japan Forum (pp. 1-26). Routledge.

Morgan, G., \& Takahashi, Y. (2002). Shareholder Value in the Japanese Context. In Competition \& Change 6 (2), pp. 169-191.

Nakano, M., Otsubo, F. \& Takasu, Y. (2014). Effects of Accounting Conservatism on Corporate Investment Levels, Risk Taking, and Shareholder Value (No. 14-E-10). Institute for Monetary and Economic Studies, Bank of Japan.

Osawa, M., Kim, M.J. \& Kingston, J. (2013). Precarious work in Japan. American Behavioral Scientist, 57(3), pp. 309-334.

Palley, T. (2007). Financialization: what it is and why it matters. The Levy Economics Institute and Economics for Democratic and Open Societies Washington D. C.

Patrick, H. (2015). Japan's Abenomics bumps along. Center on Japanese Economy and Business, Columbia Business School.

Peng, I. (2012). Economic Dualization in Japan and South Korea. The Age of Dualization: The Changing Face of Inequality in Deindustrializing Societies, 226-249.

Rappaport, A. (1986). Creating shareholder value: the new standard for business performance. Free press.

R Core Team (2017). R: A Language and Environment for Statistical Computing. Vienna, Austria. Retrieved from https://www.R-project.org/

Song, J. (2012). Economic distress, labor market reforms, and dualism in Japan and Korea. Governance, 25(3), 415-438.

SSCC (2016). Mixed Models: Diagnostics and Inference. Social Science Computing Cooperative. UW-Madison.

Stewart, G. B. (1991). The quest for value. Harper Collins.

Stockhammer, E. (2010). Financialization and the global economy. Political Economy Research Institute Working Paper, 242.

Sullivan, D. (1994). Measuring the degree of internationalization of a firm. Journal of international business studies, 25(2), 325-342.

Tohyama, H. (2012). Labor and financial-market risks and welfare spending: a comparative study with a special emphasis on Japan, In Boyer, R. Uemura, H. \& Isogai, A. (Eds.), Diversity and Transformations of Asian Capitalisms, Abingdon and New York: Routledge, pp. 72-90. 
Thelen, K., \& Kume, I. (2006). Coordination as a political problem in coordinated market economies. Governance, 19(1), 11-42.

The Japanese Institute for Labor (2010). Labor Situation in Japan and Its Analysis: Detailed Exposition 2009/2010.

TSE (2017). 2016 Shareownership Survey, Tokyo Stock Exchange, Inc., June.

Uemura, H. (2012). Institutional Changes and the Transformations of the Growth Regime in the Japanese Economy: Facing the Impact of the World Economic Crisis and Asian Integration. In Boyer, R., Uemura, H., \& Isogai, A. (Eds.), Diversity and Transformations of Asian Capitalisms, Abingdon and New York: Routledge, pp. 15-30.

van der Zwan, N. (2014). Making sense of financialization. In Socio-Economic Review 12 (1), pp. 99-129.

Watanabe, R. H. (2015). Institutional Change Under Neoliberal Pressure: Japanese Regulatory Reforms in Labor and Financial Markets. Asian Politics \& Policy, 7(3), 413-432.

Wickham, H. (2009). ggplot2: Elegant Graphics for Data Analysis. Springer-Verlag, New York.

Witt, M.A. \& Jackson, G. (2016). Varieties of Capitalism and institutional comparative advantage: A test and reinterpretation. Journal of International Business Studies, 47(7), pp.778-806.

Yamada, T. \& Hirano Y. (2015). Multinationalization of Japanese firms and dysfunction of companyist régulation. The Theory of Regulation in Times of Crises - International Conference Research \& Regulation 2015-June 10-12, 2015 Université Paris-Diderot, Paris

Yoshikawa, T., Phan, P. H., \& David, P. (2005). The impact of ownership structure on wage intensity in Japanese corporations. Journal of Management, 31(2), 278-300.

Yoshikawa, T., Tsui-Auch, L. S., \& McGuire, J. (2007). Corporate governance reform as institutional innovation: The case of Japan. Organization Science, 18(6), 973-988.

Yun, J.-W. (2015). The setback in political entrepreneurship and employment dualization in Japan, 1998-2012. British Journal of Industrial Relations. 


\section{Previous CEAFJP Discussion Papers}

\section{DP 17-05 (November 2017)}

"Female Board of Directors and Organisational Diversity in Japan", Yukie Saito (CEAFJP Associate Researcher, University of Geneva, Institut de Recherches Sociologiques)

\section{DP 17-04 (August 2017)}

"Keiretsu Divergence in the Japanese Automotive Industry: Why Have Some, but Not All, Gone?", Akira Takeishi (Graduate School of Economics, Kyoto University; CEAFJP Visiting Researcher) et Yoshihisa Noro (Mitsubishi Research Institute, Inc.)

\section{DP 17-03 (June 2017)}

"Globalization and Support for Unemployment Spending in Asia: Do Asian Citizens Want to Embed Liberalism?", Sijeong Lim (University of Amsterdam) et Brian Burgoon (University of Amsterdam) ; Prizewinners of the SASE/FFJ Best Paper Award.

\section{DP 17-02 (April 2017)}

"Does 'Driving Range' Really Matter? The Hidden Cost of Internal Combustion Engine Vehicles and the Potentially New Value Proposition of Electric Vehicles: Two Cases from Countryside and Urban Side of Japan", Hidetada Higashi (2016 CEAFJP/Valeo Fellow)

\section{DP 17-01 (March 2017)}

"How Can We Understand the Differences between France and Japan in the Growth of Shared Mobility Services? The Paradox of Trust and its Social Construction", Naoko Abe (2016 CEAFJP/Renault Fellow)

\section{DP 16-03 (September 2016)}

"Parameter Bias in an Estimated DSGE Model: Does Nonlinearity Matter?", Yasuo Hirose (Faculty of Economics, Keio University) and Takeki Sunakawa (Graduate School of Public Policy, University of Tokyo)

\section{DP 16-02 (April 2016)}

"Financialization and Industrial Policies in Japan and Korea: Evolving Complementarities and Loss of Institutional Capabilities", Sébastien Lechevalier (EHESS), Pauline Debanes (EHESS), and Wonkyu Shin (Kyung Hee University)

\section{DP 16-01 (April 2016)}

"How Do Credit Hours Assure the Quality of Higher Education? Time-Based vs. Competency-Based Debate", Ayaka Noda (National Institution for Academic Degrees and Quality Enhancement of Higher Education (NIAD-QE)

\section{DP 15-04 (December 2015)}

"Government Policy and the Evolution of Japan's Photovoltaic Industry, 1961-2014", Maki Umemura (Cardiff University, 2015 CEAFJP/Michelin Fellow) 


\section{DP 15-03 (December 2015)}

"Japan's Financial Crisis and Lost Decades", Naohisa Hirakata (Bank of Japan), Nao Sudo (Bank of Japan), Ikuo Takei (Bank of Japan), Kozo Ueda (Waseda University, 2015 CEAFJP/Banque de France Fellow)

\section{DP 15-02 (May 2015)}

"Can Increased Public Expenditure Efficiency Contribute to the Consolidation of Public Finances in Japan?", Brieuc Monfort (CEAFJP Associate Researcher)

\section{DP 15-01 (May 2015)}

"Policy Regime Change Against Chronic Deflation? Policy Option under a Long-Term Liquidity Trap", Ippei Fujiwara (RIETI, Keio University, Australian National University), Yoshiyuki Nakazono (Yokohama City University), Kozo Ueda (Waseda University, 2014 CEAFJP/Banque de France Fellow) 